\title{
A Comprehensive Review on the Common Emerging Diseases in Quails
}

\author{
Wafaa A. Abd El-Ghany \\ Poultry Diseases Department, Faculty of Veterinary Medicine, Cairo University, 1211, Giza, Egypt \\ Corresponding author’s E-mail: wafaa.ghany@yahoo.com; ORCID: 0000-0003-1686-3831
}

Received: 06 Oct. 2019

Accepted: 13 Nov. 2019

\begin{abstract}
The poultry industry is considered an important sector that meets the great demand for protein sources all over the world. Now, quails are recognized as promising and important alternative species with many advantages over other poultry species. In many countries around the world, quail meat has achieved great popularity as a good source of protein and other important nutrients. However, there are some limitations and challenges to quails production. One of them is the susceptibility to some viral, bacterial, mycotic and parasitic diseases that can adversely affect quails. Many of the diseases that affect quails cause severe economic losses in quail industry due to a decrease in growth performance, poor feed conversion, reduction in hatchability, increased mortality and treatment costs. There are limited research and literature dealing with different disease and conditions affecting quails. Therefore, the aim of this work was to present a comprehensive review of the most important emerging diseases affecting quails worldwide.
\end{abstract}

Key words: Bacteria, Virus, Mycosis, Myctoxicosis, Parasites, Quail

\section{INTRODUCTION}

The term quail refers to medium-sized birds belonging to various genera of family Phasianidae. There are two important species, the Japanese quails (Coturnix japonica) and Bobwhites quails (Colinus virginianus) which considered domestic birds since $14^{\text {th }}$ century (Arya et al., 2018).

In recent years, the quail industry has created a huge impact and has been widely distributed in several countries around the world (Murakami, 1991; Redoy et al., 2017). Quails production is more profitable because it requires less investment to start and provides quick returns with a higher cost-benefit ratio. Quail farming is gaining popularity because quails are easy to manage and small in size thus they can be raised within small floor space (Ruskin, 1991; Edris et al., 2004). Moreover, less feed requirements, rapid growth rate, palatable meat, high egg production, high nutritional value of meat and egg, early sexual maturity, short generation interval (3-4 generations per year) and short incubation period are other benefits of quail rearing (Hassan et al., 2017; Yambayamba and Chileshe, 2019).
The advancement in quail production is being hampered by some management factors, infectious and non-infectious diseases (Barnes and Gross, 1997). Infectious diseases are common in quails reared under intensive production system (Paulillo, 1989). As quails are related to poultry, several diseases affecting quails are similar to those in chickens and turkeys (Myint and Carter, 1988).

Accordingly, this review highlighted the most important viral, bacterial, mycotic and parasitic diseases as well as mycotoxicosis affecting quails species worldwide.

\section{Viral diseases}

\section{Adenovirus}

In Bobwhite quails, adenovirus induced acute respiratory contagious infection called quail bronchitis (Olsen, 1950; DuBose et al., 1958). This disease is more severe in young quails less than 3-week-old and leads to 100\% morbidity and 50\% mortality (Jack and Reed, 1990). Quail bronchitis virus was recently isolated from 5day to 8-week old Bobwhite quails raised in Minnesota, USA. 
The birds showed respiratory manifestations and high mortality, also histopathological findings included mucus in trachea, congested lungs, caseous airsacculitis, enlarged spleen, urates on internal organs, and necrotic foci on the liver (Singh et al., 2016).

Inclusion Body Hepatitis (IBH), caused by avian adenovirus-1, occurs in Bobwhite quails less than 3-weekold (Jack et al., 1987). However, the outbreak of IBH has been described in adult Japanese quail (Grewal et al., 1994). In a study by Singh et al. (1995), Japanese quails more than 4-week-old inoculated intraperitoneally with IBH adenovirus and showed congested pneumonic lungs, swollen mottled liver and necrotic kidney with intranuclear inclusion bodies. In addition, quail strains of IBH virus were pathogenic for broiler chickens after experimental inoculation.

Egg Drop Syndrome-76 (EDS-76), caused by avian adenovirus-3, was isolated from natural outbreaks in Japanese quail and the virus was serologically indistinguishable from that of chicken (Dash and Pradhan, 1990; Kataria et al., 1991; Dash and Pradhan, 1992). In a large study, the EDS-76 virus caused histopathological changes in the genitalia and spleen, decreased egg quantity and egg quality, increased virus antibody titers and total protein levels in laying Japanese quails (Mohapatra et al., 2014).

Experimental infection of 12-day-old quails with Chicken Embryo Lethal Orphan (CELO) virus and Avian Adeno-Associated Virus (AAAV) significantly increased CELO virus-produced mortality while double infections with high doses of AAAV induced a delay in mortality (Bagshaw et al., 1980).

The adenoviral inclusions were detected in the intestinal epithelia and glandular epithelium of gizzard and conjunctiva in less than 3-week-old quails with depression, ruffled feathers, diarrhea and high mortality (Tsai et al., 1998). Moreover, adenovirus inclusion bodies were observed in the proventriculus of Bobwhite quails and chickens. In wild Bobwhite quails with hepatic inclusion bodies, adenovirus serotype TR-59 was identified in their caeca (King et al., 1981).

Good management practice and biosecurity measures are very important to prevent adenovirus infections. There is no treatment for adenovirus infection. Water treatment with minerals and vitamins is critical to increase quail immunity (Singh et al., 2016).

\section{Avian influenza}

Avian Influenza Virus (AIV) was first recorded in Italy in Japanese quail under 3 months of age with respiratory manifestations and high mortalities (Nardelli et al., 1970). In several countries, many subtypes of AIV outbreaks have been detected in quail flocks (Guo et al., 2000; Wee et al., 2006; Lee et al., 2008; Yee et al., 2011; Arya et al., 2018). Japanese quail is considered a vehicle for adaptation of AIV strains in wild birds which is a means to generate new variant strains able to cross species barrier and infect different poultry species and possibly human (Perez et al., 2003; Wan and Perez, 2006; Wang et al., 2008). Chicken and quails were found to be highly susceptible to infection Highly Pathogenic (HP) AIV H5N1; while ducks have higher resistance and served as carriers (Hulse-Post et al., 2005; Tiensin et al., 2005). Moreover, HPAIV H5N1 strains isolated from geese were capable of causing disease in quails, with a longer period of virus shedding than that in chickens (Webster et al., 2002; Jeong et al., 2009; Saito et al., 2009). However, it was found that Japanese quails are resistant to HPAIV H5N3, which is pathogenic for turkeys, thus they could transmit this lethal virus to chickens (Tashiro et al., 1987). A study conducted in Korea revealed that chickens, ducks, and quails experimentally infected with HPAIV H5N1 had various symptoms, mortality, viral titers, and virus shedding. The mentioned study suggested that duck and quail farms should be regularly monitored to prevent virus transmission to another host (Jeong et al., 2009). European quails experimentally infected with HPAIV H7N1 and H5N1 showed severe nervous manifestations with histopathological changes and mortality rates of $67 \%$ and 92\% in H7N1 and $\mathrm{H} 5 \mathrm{~N} 1$ challenged birds, respectively. While birds challenged with Low Pathogenic (LP) AIV H7N2 showed no clinical or pathological conditions. However, viral shedding and transmission to naive quail were observed for all types of AIV and drinking water and feathers were possible routes of HPAIV transmission (Bertran et al., 2013). In Egypt, a study on quails detected maternal antibodies against AIV and also evaluated immune responses to inactivated AI vaccines containing $\mathrm{H} 5 \mathrm{~N} 1$ and $\mathrm{H} 5 \mathrm{~N} 2$ viruses. The results revealed high to moderate levels of maternal immunity on the first and fifth days of age and low levels on the seventh day. In addition, vaccination at 8-day-old quails induced satisfactory titers at third week of post-vaccination, while the highest titers were detected at fourth and fifth weeks after vaccination (Saad et al., 2010). Moreover, H5N8 strain was detected in only one domestic Egyptian quail farm and it was also isolated from 2 out of 3 wild quail samples (Shehata et al., 2019). Outbreaks of AIV H9N2 revealed stable lineages in chickens and other poultry species such as quails (Naeem et al., 1999). In Hong Kong, 16\% of quails in markets 
were found to be positive for H9N2 viruses (Guan et al., 2000). The amino acid patterns of hemagglutinin of AIV H9 in quails were found to be intermediate between those in duck and in chicken, which explains the susceptibility of quail to duck AIV H9 (Perez et al., 2003). AIV could be detected using indirect immunofluorescent assay in the muscles and internal organs of quails, chickens, and ducks (Antarasena et al., 2006). Prevention of avian influenza in quails mainly occurs through vaccination combined with implementing biosecurity measures by thorough cleaning and disinfecting and restricting the personal movements on the farm. In a study conducted in China, the protective efficacy of inactivated H5N1 (clade 1) influenza vaccine (NIBRG-14) before challenge with heterologous A/Swan/Nagybaracska/01/06 (H5N1 clade 2.2) strain was tested in quails; the results revealed protection of challenged birds and absence of the virus in cloacal swabs, but immunized birds had low antibody titers (Sarkadi et al., 2013). In Indonesia, it was found that vaccination of brown quails with inactivated bivalent $\mathrm{H} 5 \mathrm{~N} 1$ clades 2.1.3 and 2.3.2 at ages 24 and 45 days induced significant protection, although the virus shedding continued 7 days post-vaccination (Indriani and Dharmayanti, 2016).

\section{Newcastle disease}

The pathogenicity of Newcastle Disease Virus (NDV) in quails depends on the virus strain, dose, and route of administration (Oladele et al., 2008). Quails are considered a susceptible host for NDV and have a nonnegligible role in transmission of the virus to chickens. Therefore, quails should be vaccinated against the virus to protect them and prevent transmission to chickens (Sharawi et al., 2015). In Northern India, an outbreak of ND was recorded in Japanese quail aged 22-week-old with central nervous system manifestations, $30 \%$ mortality, and $20 \%$ morbidity. (Gowthaman et al., 2013). In Iran, loss of appetite, decreased egg production, diarrhea, and nervous symptoms were recorded in quails infected with NDV (Shoushtari et al., 2007). There are several reports on outbreaks of ND in Japanese quail flocks (Kaleta and Baldauf, 1988; Chandrasekaran and Aziz, 1989; Islam et al., 1994). Islam et al. (2016) found that NDV had the highest prevalence rate $(11.35 \%)$ among the isolated viral diseases (25.21\%) from 476 quails in Bangladesh. The experimental infection of quails with NDV revealed that oculo-nasal inoculation of 17-week-old Japanese quails with a velogenic NDV strain resulted in no morbidity or mortality, although broilers chickens that were in contact with infected birds showed clinical signs of ND with $100 \%$ mortality. These findings suggest that quails can be
NDV carriers (Lima et al., 2004). Inoculation of velogenic strain of NDV in 3-6-week old Japanese quail induced different mortality rates according to route of inoculation, as follows: $13 \%$ (Usman et al., 2008) and 100\% (Mohamed and Abdel Hafez, 2016) using oculo-nasal route, 25\% using intracoelomic route (El-Tarabili et al., 2009), 3\% (Oladele et al., 2008) and 40\% (Sharawi et al., 2015) using intramuscular. Recently, in a study by Susta et al. (2018), 2-week-old Japanese quails were inoculated through the oculo-nasal route with 4 virulent NDV strains of different genotypes. The results indicated mild to moderate disease with mortality rate ranged from $28 \%$ to less than $10 \%$, neurological signs with suppurative encephalitis. In addition, the virus replication was moderate in inoculated birds, but minimal in contact birds. Moreover, inoculated birds with NDV strains originated from quails showed high virus shedding, while high virus transmission occurred in birds inoculated with virus originated from chicken. Mazlan et al. (2017) proved susceptibility of Japanese quail to experimental infection with genotype VII NDV based on the development of specific clinical signs, detection of the virus antigen in the tissues and increase in the titers of haemagglutinating antibodies. The immune response to NDV vaccines in different lines of Japanese quail was studied and the results showed that double vaccination at 4 and 6 weeks of age with inactivated vaccine induced high antibody level in the high line breed that was $24 \%$ greater than control one, but in the low line, the antibody level was $37 \%$ less than that in the control (Takahashi et al., 1984). Vaccination using both living vaccines like La Sota or Hitchner B1 and inactivated vaccines is very important for efficient eradication of NDV in quails (Lima et al., 2004 and Paulillo et al., 2009).

\section{Poxvirus}

Although avian pox has been reported in a wide variety of domestic and wild birds (Bolte et al., 1999), the infection is not common in quails (Rinaldi et al., 1972; Crawford et al., 1979; Davidson et al., 1980; Poonacha and Wilson, 1981). Diphtheritic form of avian pox virus in the respiratory tract was found to induce significant mortality (Tripathy and Reed, 1997). Quail pox virus is a distinct species of the genus Avipoxviridae, and the virus had no immunologic relationship to pigeon and fowl poxviruses. Moreover, in areas where poultry is reared in close proximity to quails, cross-infection is possible (Winterfield and Reed, 1985; Ghildyal et al., 1989). Dry pox in quails causes lesions with a gray to yellow or dark brown discoloration and single or multiple nodules with 
crusts in variable sizes on the comb, eyelids, and the other poorly feathered areas of the body (Singh et al., 1992; Gülbahar et al., 2005). Vaccination of quails is necessary for endemic areas. Quail pox can affect chickens. Fowlpox and pigeon pox vaccines could be considered good vaccines to control poxvirus infection in quails (Promkuntod et al., 2003).

\section{Tumors}

There are few reports on naturally occurring lymphoproliferative disease or Marek's Disease (MD) in Japanese quails. The MD Virus (MDV) is a causative agent of spontaneous tumor disease in quails (Pradhan et al., 1985; Adedeji et al., 2019) and can be transmitted to chickens by contact exposure (Kenzy and Cho, 1969). A study found a positive association between the incidence of lymphomatous changes and the presence of MDVspecific antigen on a quail flock (Kobayushi and Mikami, 1986). It has been reported that JM strain of MDV could be isolated by cell culture from quails at 7-8 days postinoculation. (Khare et al., 1975), however, the same strain was not recovered from quail by direct culture of kidney tissue (Mikami et al., 1975). Quails inoculated with HPRS-16 strain of MDV showed lower viremia than that of chickens inoculated with the same strain (Powell and Rennie, 1984). Quails could be experimentally infected with MDV of chicken origin (Dutton et al., 1973; Fujimoto et al., 1975). The MDV was detected in natural lymphoproliferative outbreaks in eight flocks of Japanese quails. (Imai et al., 1990). Avian Leukosis Virus (ALV) could induce tumors in Japanese quails (Wight, 1963) and quails with lymphoproliferative disease had antibodies against ALV subgroup A (Schat et al., 1976). Recently, it was observed that intraperitoneal inoculation of quails with ALV subgroup A induced transient viremia, intermittent cloacal shedding and mild lesions in infected quails (Zhang et al., 2019). Quails are susceptible to experimental infection with reticuloendotheliosis virus (Theilen et al., 1966). A malignant tumor resembling reticuloendotheliosis was reported under natural conditions in quails (Carlson et al., 1974; Schat et al., 1976). In Japanese quail, avian myeloblastosis virus was able to produce a wide spectrum of neoplasms similar to that observed in chickens; however, contrary to what is observed in chickens, acute myeloblastic leukemia was not found in Japanese quail (Moscovici and Macintyre, 1966). Genetic selection of tumors-resistant breeds is very important to prevent tumor development in quails.

\section{Bacterial diseases}

\section{Salmonellosis}

Today, avian salmonellosis is still a major problem facing quail production and needs to be solved. Many reports demonstrated the isolation of different Salmonella spp. from quails (Erdogrul et al., 2002; Takata et al., 2003; Aarestrup et al., 2005). Sander et al. (2001) and Bacci et al. (2012) isolated Salmonella enterica in quail's carcasses. The frequency of salmonellosis in young quails of two flocks in Bangladesh was $6.73 \%$ and $11.97 \%$ (Islam et al., 2003, 2016). Al-Nakhli (2005) isolated different types of Salmonella spp. causing paratyphoid infection among Japanese quails in Saudi Arabia. In Brazilian quail flocks, Freitas et al. (2013) identified $S$. enterica subspecies Enterica; S. Corvalis, S. Give, S. Lexington, S. Minnesota, S. Schwarzengrund, S. Rissen, and $S$. Typhimurium from meconium samples of one-dayold quail chicks. In addition, Salmonella spp. were isolated from cloacal swabs of Kelantan quails in Malaysia (Palanisamy and Bamaiyi, 2015). Udhayavel et al. (2016) confirmed the identification of $S$. enterica from heart blood swabs, liver and spleen samples collected from 8day-old Japanese quails in India. Recently, in Nigeria, a total of 19 out of 200 quail's eggs swabs were identified as Salmonella spp. (Mera et al., 2017). Moreover, it was found that 10 out of 75 (13.33\%) quail samples from three farms in Bangladesh were positive for Salmonella spp. of which seven isolates were motile Salmonella (Jahan et al., 2018). Barde (2014) demonstrated that S. Gallinarum in Japanese quails causes septicemic disease with distribution of the organism in major organs, greenish-yellow diarrhea, high mortality, marked drop in egg production and congestion with enlargement of internal organs, which is similar to that in chickens. Hamed and Hassan (2013) proved that water supplementation with acetic acids, organic acids mixture, and hydrochloric acid reduced $S$. Enteritidis colonization in the gut and internal organs as well as inducing high protection from morbidity and mortality in quails. Nowadays, in-ovo inoculation of antibiotics is considered a new trend to prevent the possibility of bacterial pathogen transmission through eggs (Tavakkoli and Gooshki, 2014). In a study by Jahan et al. (2018), the in-vitro antibiotic sensitivity test of Salmonella strains isolated from quails showed that $100 \%$ of strains were resistant to erythromycin and tetracycline, but were sensitive to ciprofloxacin and imipenem, $90 \%$ of strains were resistant to colistin sulfate and $80 \%$ were sensitive to neomycin. Also, all Salmonella isolates showed multidrug resistance. 


\section{Colibacillosis}

Septicemic colibacillosis caused by Escherichia coli (E. coli) is an infectious avian disease that has been commonly reported in chicken, turkeys, ducks, and quails (Da Silva et al., 1989). Infection with E. coli was associated with several diseases including yolk sac infection, septicemia, airsacculitis, peritonitis, polyserositis, omphalitis, cellulitis, coligranuloma and enteritis (Barnes and Gross, 1997; Dho-Moulin and Fairbrother, 1999). Arenas et al. (1999) isolated E. coli serogroup O165 from the internal organs of 4-6 day old Japanese quails with $90 \%$ mortality rate. The E. coli infection caused hepatitis and pericarditis in Japanese quails at 21 days and 11 months of age (Ito et al., 1990), and coligranulomatosis in common quails at the ages of 812 months (Da Silva et al., 1989). In Bobwhite quails, $E$. coli was isolated from specimens of liver, spleen, and intestine (Radi, 2004). Roy et al. (2006) isolated E. coli serogroups such as $\mathrm{O} 4, \mathrm{O} 9, \mathrm{O} 38, \mathrm{O} 42$, and $\mathrm{O} 88$ from diseased Japanese quail, dead-in-shell embryos, fluff samples, footbath and drinking water samples in a hatchery. The E. coli isolates cultured from infected Japanese quails belonged mainly to serogroup O9 (54.5\%) and the same serotype was also predominant in the hatchery environment (Roy et al., 2006). The capability of $E$. coli serogroup $\mathrm{O} 2$ to produce dose-dependent cellulitis, pericarditis, perihepatitis, and septicemia in quails was recorded (Burns et al., 2003; Nain and Smits, 2011). In Iraq, 37 out of $203(18.2 \%)$ bacterial isolates obtained from liver, lung, gizzard, and intestine of 30 healthy quails identified as E. coli (Hamad et al., 2012). In India, 32 out of 154 E. coli isolates $(20.77 \%)$ were detected in different organs of quail birds (Manickam et al., 2017). However, in Nigeria, 21 out of 200 eggs swabs identified as E. coli, of which 11/21 (52.4\%) were from eggshell swabs and 13/21 (61.9\%) were from internal egg contents (Mera et al., 2017). In Bangladesh, the prevalence rate of colibacillosis in quails was $15.34 \%$, which was the highest rate among bacterial disease (Islam et al., 2016). The isolation rate of E. coli among Japanese quail of Sylhet and Narsingdi region in Bangladesh was $5.17 \%$ and $5.7 \%$, respectively (Islam et al., 2003; Uddin et al., 2010). Antibiotic sensitivity tests should be used to select the suitable specific antimicrobials for the treatment of specific E. coli serotypes.

\section{Clostridial infection}

Clostridial enteritis is a common problem in avian species (Ficken and Wage, 1997; Prescott, 2016). Ulcerative enteritis caused by Clostridium colinum ( $C$. colinum) was recorded as an epidemic disease in Bobwhite quails (Berkhoff, 1975 and Cooper et al., 2013). Some outbreaks of highly contagious ulcerative enteritis have been described (Berkhoff and Kanitz, 1976; Berkhoff, 1985). Radi (2004) isolated C. perfringens from the intestine of Bobwhite quail with a history of anorexia, diarrhea, dehydration, weight loss, and acute death. In addition, ulceration and perforation of intestine, peritonitis, and multifocal necrotizing hepatitis were observed in histopathological examination. The detection limit of C. colinum in quails was $1.6 \times 10^{4}$ colony forming units/g feces (Bano et al., 2008). Ulcerative enteritis-like disease due to $C$. perfringens type A was attributed as the cause of mortality in 10 to 16-week-old Bobwhite quails (Shivaprasad et al., 2008). Also, C. sordellii was associated with ulcerative enteritis in quails (Crespo et al., 2013). Penicillin-streptomycin was the most effective prophylactic and streptomycin was the most effective therapeutic agent for ulcerative enteritis in Bobwhite quail (Brown et al., 1970). Five days water treatment with tylosin was effective in controlling ulcerative enteritis in Bobwhite quails (Jones et al., 1976). Beltran-Alcrudo et al. (2008) described an outbreak of ulcerative enteritis caused by $C$. colinum, C. perfringens and Eimeria spp. in Bobwhite quail farm and found that combined treatment with an anticoccidial drug and tylosin was effective in controlling clinical disease. The addition of bacitracin (50 $\mathrm{g} /$ ton feed) is recommended as a preventative measure against the disease in quails. Adoption of hygienic measures such as wearing disposable shoes and gloves is very crucial to prevent spread of infection (Cooper et al., 2013).

\section{Pasteurellosis}

Pasteurellosis or Fowl Cholera (FC) in quails was first reported by Hinshaw and Emlen (1943) in captive California Valley quail (Lophortyx caflfornicus). Later on, the disease was described in different species of quails with a high mortality rate (13\%) (Myint and Carter, 1988). Pasteurella multocida (P. multocida) serotype A:3 causing acute FC with high mortality was first reported in commercially raised Bobwhite quail in America (Panigrahy and Glass, 1982). Natural outbreaks of FC were reported in quails in Burma (Naveen and Arun, 1992), USA (Glisson et al., 1989), India (Chadran et al., 1995), Japan (Gowthaman et al., 2013), and Iraq (Hamad et al., 2012). In addition, signs and lesions of FC in quails were reported previously (Glisson et al., 1989; Bermudez et al., 1997; Goto et al., 2001; Odugbo et al., 2004; Akpavi et al., 2011). The mortality rate in natural outbreaks of FC 
in quails can vary from 60\% (Naveen and Arun, 1992; Miguel et al., 1998) to 99\% (Bermudez et al., 1997). Japanese quails were susceptible to experimental infection with $P$. multocida serotypes A: 1,3 and 4 and showed signs of weakness, inappetence, and sudden death. On pathological examination, petechial and ecchymotic hemorrhages on the heart and breast muscles as well as congestion of heart, liver, and lung were observed (Yakubu et al., 2015). Similar signs with $90 \%$ mortality were recorded in Japanese quails within $24 \mathrm{~h}$ postinoculation with $P$. multocida serotype A: 4 (Akpavi et al., 2011). In India, the majority of $P$. multocida belonging to serotypes A: 1, 3 and 4 were associated with FC in quails (Kumar et al., 2004), however, P. multocida was isolated and molecularly identified from 330 apparently healthy quail chicks (8-day-old) with severe liver congestion and necrosis as well as bronchopneumonia (Babu Prasath et al., 2018). In Africa, a recurrent outbreak of FC in a Japanese quail farm was attributed to rats cohabiting quail houses (Mwankon et al., 2009). Treatment of Japanese quails infected with $P$. multocida using some antimicrobials (sulfonamides, oxytetracycline, doxycycline, neomycin, and norfloxacin) administered in the drinking water for five consecutive days was highly effective (Rigobelo et al., 2013).

\section{Mycoplasmosis}

Madden et al. (1967) reported the first isolate of Mycoplasma gallisepticum (M. gallisepticum) from a commercial Bobwhite quail flock with chronic respiratory disease. After, several quail cases of mycoplasmosis infection were reported (Tiong, 1978; Nascimento and Nascimento, 1986; Reece et al., 1986). Quails with mycoplasmosis indicate fibrinous perihepatitis, pericarditis and pleuritis, caseous materials in the air sacs and congested trachea (Barnes and Gross, 1997; Chauhan and Roy, 2008; Islam et al., 2016). Both M. gallisepticum and $M$. synoviae have been frequently isolated from quails as reported previously (Nascimento and Nascimento, 1986; Nascimento et al., 1997 and 1998). Infection with $M$. gallisepticum was serologically determined for the first time in 10-week-old quails with nasal discharge, mortality and swollen infraorbital sinuses in the Aydin region of Turkey (Türkyilmaz et al., 2007). In Bangladesh, the isolation rate of Mycoplasma from diseased and dead quails with chronic respiratory diseases was 5\% (Islam et al., 2003, 2016). In a layer flock suffering from respiratory manifestation, mortality and egg production loss, $M$. gallisepticum were detected in 15 out of 17 (88.8\%) quails and 12 out of $15(80 \%)$ of birds showed mixed infections with $M$. gallisepticum, $P$. multocida and $E$. coli (Murakami et al., 2002). Concurrent infection of $M$. gallisepticum and Subulura brumpti was recorded in an 8week-old Japanese quail breeder with mortality, caseous airsacculitis, and drop in egg production (Arulmozhi et al., 2018).

\section{Infectious coryza}

Infectious Coryza (IC), caused by Avibacterium paragallinarum (A. paragallinarum), is an upper respiratory disease in chickens and quails (Blackall and Hinz, 2008). Quail of all ages are susceptible to IC infection and the pathogen was isolated from naturally and experimentally infected Japanese quails (Cundy, 1965; Reece et al., 1981). Although quails are susceptible to IC, reports on isolation and identification of $A$. paragallinarum were rare (Blackall and Yamamoto, 1989). In a study, 53 Japanese quails representing from five commercial farms suffering typical IC, 8 isolates of $A$. paragallinarum were identified and molecularly characterized (Thenmozi and Malmarungan, 2013). In Indonesia, 5 out of 9 isolates (55.5\%) of $A$. paragallinarum were identified from quails with typical sinusitis and facial edema. However, 3 out of 5 isolates were serologically identified as serovar B (Wahyuni et al., 2018). Recently, the migration pattern of $A$. paragallinarum was studied after experimental infection of Japanese quails and chicken. The results revealed prominent localization of the bacteria at 12 hours postinfection in nasal turbinates of quails and then decline in immunostaining intensity in the nasal tissue by 72 hours post-infection, indicating that the infection was resolved by the resident immune cells or by certain inherent innate immune factors in the nasal passage (Balouria et al., 2019).

Different antimicrobials have been used to treat IC infection, but many of them only lower the severity of the disease without complete curing the disease. Repeated treatments lead to the development of resistance to the used antibiotics (Tabbu, 2000). The antibiogram of $A$. paragallinarum in Japanese quails revealed complete (100\%) resistance to ampicillin, neomycin, pefloxacin, cocotrimoxazole, furazolidone, streptomycin, cephalexin and amikacin, $90 \%$ to gentamycin and $70 \%$ to oxytetracycline (Thenmozi and Malmarungan, 2013). Appropriate treatment requires antibiotic sensitivity tests to select effective and efficient drugs against the infection (Wahyuni et al., 2018). Diseased quails should be isolated from healthy ones and preventive sanitary measures, such as cleaning and disinfection of utensils, washing hands, 
and change shoes during visiting the farm, should be applied (Blackall and Yamamoto, 1989; Blackall and Hinz, 2008)

\section{Chlamydiosis}

The correlation between the latent and lethal forms of avian chlamydiosis by using a Japanese quail as a model was examined. The results demonstrated that the latent chlamydial infection was converted to the lethal form in quails receiving cyclophosphamide treatment (Takashima et al., 1996). Chlamydia psittaci was histopathologically identified in a flock of Bobwhite quail aged 2-4 weeks old with $100 \%$ morbidity and 40-50\% mortality, stunting and yellow/green diarrhea (Erbeck and Nunn, 1999). Tetracycline, erythromycin, azithromycin, and fluoroquinolones were proven to be effective against chlamydia infection (Takashima et al., 1996).

\section{Mycotic diseases}

\section{Aspergillosis}

Aspergillosis is a respiratory disease detected in a Japanese quail breeder with multiple grey lung nodules and airsacculitis (Basheer et al., 2017). Aspergiluus flavus (A. flavus) was associated with mycotic salpingitis in Japanese quails and white to grayish nodules $(2-5 \mathrm{~mm}$ in diameter) were found on the serosal surface of oviduct (Singh et al., 1994). Also, natural and experimental aspergillosis caused by A. fumigatus and A. flavus was recorded in broiler quails (Gumussoy et al., 2004; Borah et al., 2010). In Bangladesh, the prevalence rate of aspergillosis was $3.99 \%$ among 476 diseased and dead quails. (Islam et al., 2016). Early treatment could be effective in case of mild or moderate lesions. Some medicaments including ketoconazole and amphotericin-B could be used to control aspergillosis (Dhama et al., 2012). Using copper sulfate for treatment of birds or litter can help in reducing fungal growth (Dyar et al., 1984). Birds severely affected should be culled from the flock. Strict sanitary and hygienic measures in the hatchery are very important (Beernaert et al., 2010). Good ventilation, good litter quality, proper stocking density and keeping feeders dry in the flocks are crucial to prevent Aspergillus growth (Kunkl, 2003).

\section{Candidiasis}

Experimental oral infection with Candida albicans (C. albicans) was successful in Japanese quails with severe macroscopic and microscopic hyperkeratosis along the digestive tract (Asrani et al., 1993). Cutaneous candidiasis with isolation of $C$. albicans was detected in the footpad lesions of Japanese quails (Sah et al., 1982). Adequate cleaning and disinfection, proper management, vitamin A supplementation and stopping of antibiotic administration are important for reducing the incidence of candidiasis (Dhama et al., 2013). Treatment with antifungal drugs such as nystatin, fluconazole or itraconazole is useful (Tiwari et al., 2011).

\section{Mycotoxicosis}

Mycotoxins are secondary toxic metabolites produced by fungal species under high temperature and high humidity during storage of poultry diets. Fumonisins B1 produced by Fusarium spp. is considered one of the most important mycotoxins that adversely affect the kidney tubules in the Japanese quail chicks fed with 200 ppm in diet for 21 days (Khan et al., 2013). Ochratoxin A is a fungal metabolite produced by Penicillium and several species of Aspergillus has embryotoxic, teratogenic and nephrotoxic effects on Japanese quail chicks at a dose of $16.5 \mathrm{mg} / \mathrm{kg}$ of body weight (Prior et al., 1976; Khan et al., 2013; Patial et al., 2013 a and b). Moniliformin, a watersoluble fungal metabolite produced by Fusarium spp., is associated with severe hypertrophic cardiomyopathy in Japanese quails (Sharma et al., 2012). Aflatoxin is an important toxin produced by Aspergillus especially $A$. fumigatus, A. flavus, and A. parasiticus. Quails are more sensitive to aflatoxins than other poultry species (Lozano and Diaz, 2006). Chang and Hamilton (1982) found decrease in body weight of laying Japanese quails fed diet containing aflatoxin concentrations (500 to $10,000 \mu \mathrm{g} / \mathrm{kg}$ ) for 28 to 100 days. Japanese quails fed diets containing $25-100 \mu \mathrm{g} / \mathrm{kg}$ aflatoxin B1 showed poor feed intake, low egg weight and poor eggshell (Sawhney et al., 1973, Oliveira et al., 2002, Ogido et al., 2004, Oguz and Parlat, 2004, Sehu et al., 2005). The synergistic effect of aflatoxicosis and coccidiosis was studied in Japanese quails and the results revealed significant reduction in body weight and increase in oocyst production (Rao et al., 1990). Manafi (2018) mentioned that aflatoxin B1 $(1.5 \mathrm{mg} / \mathrm{kg})$ had adverse effects on performance and biochemical parameters, gut physiology and immunity of laying Japanese quails and those alterations could be bypassed through using of herbal mycotoxin binder containing antioxidants, enzymes, and diatomaceous earth minerals. In addition, Sakamoto et al. (2018) reported that aflatoxin B1 (1500 $\mu \mathrm{g} / \mathrm{kg}$ of diet) impaired hepatic function, productive performance and reduced egg weight in laying quails; however, addition of silymarin (500 $\mathrm{g} /$ ton) or adsorbent $(1 \mathrm{~kg} / \mathrm{ton})$ was not able to ameliorate the adverse effects of aflatoxins on performance and 
metabolism. It was observed that adverse effects of contamination of the diet with aflatoxin B1 in 21-day-old Japanese quails could be overcome by addition of probiotics containing Bacillus, which improved meat quality and microbial ecosystem of growing quail chicks (Kasmani et al., 2012 and 2018). Nigella sativa (black cumin seed) was found to be potent detoxifier for dietary aflatoxins in growing quails as inclusion of these seeds in the diet of quails induced significant improvement in immune responses, meat quality and intestinal E. coli populations (Rasouli-Hiq et al., 2016). Addition of glucomannan $(2 \mathrm{~g} / \mathrm{kg}$ of the diet) overcome the adverse effects of aflatoxicosis in 60-day-old Japanese quails and reduced the pathological lesions in liver, kidneys, spleen, thymus glands and bursa of Fabricius (Yavuz et al., 2017). The role of dietary Saccharomyces cerevisiae inclusion to aflatoxin-contaminated diet was studied and the results indicated significant improvements in feed consumption, body weight and feed conversion ratio of Japanese quails (Parlat et al., 2001; Atalay, 2010). Citil et al. (2007) evaluated the protective capacity of L-carnitine to prevent the adverse effects of chronic aflatoxicosis in 8-week-old Japanese quails. Feeding of 2-week-old Japanese quail chicks on different doses of hydrated sodium calcium aluminosilicate partially protected the birds from the toxic effect of aflatoxicosis regarding measuring of some biochemical parameters, body performance and pathological lesions in different organs (Eraslan et al., 2004). Moreover, Migliorin et al. (2017) found that the use of adsorbent containing aluminosilicates, yeast cell wall, silymarin and bentonite after feeding of quails with aflatoxin-contaminated diet, prevented lipid peroxidation and free radical production and resulted in reduced histopathological lesions in liver.

\section{Parasitic diseases}

\section{Coccidiosis}

Coccidiosis is often a hidden disease in quails and causes severe economic losses due to increased mortality, decreased productivity and a predisposing factor for necrotic enteritis as a secondary bacterial infection (Simiyoon et al., 2018). Earlier in Oklahoma, Eimeria spp. was detected in $28 \%$ of Bobwhite quails (Alan Kocan et al., 1979). Three Eimeria spp. (E. uzura, E. bateri and E. tsunodai) have been identified in Japanese quails (Gesek et al., 2014). Natural infections with coccidiosis in Japanese quails exhibit signs of depression, anemia and blood mixed droppings (Teixeira et al., 2004; Simiyoon et al., 2018). On pathological examination, the caecum shows ballooning appearance with severe serosal and mucosal congestion and its lumen contained foul smelled necrotic materials admixed with blood (Umar et al., 2014; Anbarasi et al., 2016; Simiyoon et al., 2018). The histopathological changes revealed damage of intestinal villi and crypt epithelial cells with multiplying endogenous stages of Eimeria and a high number of oocysts (Teixeira and Lopes, 2002; Simiyoon et al., 2018). Arafat and Abbas (2018) detected that 34 out of $107(31.78 \%)$ examined Japanese quail farms were positive for Eimeria bateri. Proper control measures should be considered in quail farms by avoiding water spillage, good stocking density, regular and hygienic disposal of litter and improving hygienic practices (Umar et al., 2014). Moreover, application of coccidiostats in the feed or coccidiocidal drugs in water is another way to control coccidiosis. Sokó et al. (2014) demonstrated that administration of toltrazuril in the drinking water completely eliminated E. bateri and induced significant reduction in E. tsunodai oocysts number in Japanese quails. A study conducted in Egypt compared the efficacy of coccidiocidal amprolium ethopabate and toltrazuril in the drinking water and prophylactic salinomycin and diclazuril as feed additives against $E$. tsunodai in Japanese quails, the results indicated that effects of curative drinking water treatments had the preference in comparison to prophylactic treatment (ElMorsy et al., 2016). The effect of feeding some herbal plants like Matricaria chamomilla on E. bateri infestation in 15-day-old quails was studied and the results revealed effective reduction of fecal oocyst shedding after treatment (Ahmadov et al., 2014). In addition, Arafat and Abbas (2018) concluded that oral immunization of 2-day-old Japanese quails with either 100 or 1000 sporulated oocysts of $E$. bateri improved weight gain and feed conversion rate as well as reduced diarrhea, intestinal lesions, and oocyst production. The FDA approved using of monensin sodium and amprolium as coccidiostats in the quail ration (El-Morsy et al., 2016). In conclusion, vaccination is a viable method to control coccidiosis in quails (Arafat and Abbas, 2018).

\section{Other parasites}

The examined intestine of Bobwhite quails revealed presence of a wide variety of nematodes, cestodes and protozoa including 27\% Subulara brumpti, 4\% Heterakis gallinarum, 6\% unidentified cestodes, 45\% Trichomonas spp., 30\% Chilomastix spp., 27\% Eimeria spp., 25\% Trichomonas gallinarum and 7\% Histomonas melegridis (Alan Kocan et al., 1979). The findings of a survey on 40 Bobwhite and Japanese quails conducted in Iran 
(Shemshadi et al., 2014) indicated that 5\% of the quails harbored Raillietina echinobothrida and Raillietina cysticillus, $20 \%$ quails harbored intestinal cryptosporidiosis and $32.5 \%$ quails had tracheal cryptosporidiosis. Microscopic examination on four young Bobwhite quails with anorexia, diarrhea, emaciation, and mortality as well as severe ulcerative enteritis, hepatic necrosis and peritonitis showed the presence of Capillaria spp., Eimeria spp. and Histomonas spp. (Roy et al., 2006). Cryptosporidiosis has been associated with high mortality in young quail with diarrhea (Hoerr et al., 1984 and 1986; Lindsay et al., 1991). Cryptosporidium infection also induced respiratory affections in quails (Tham et al., 1982). Mixed infections of Cryptosporidium spp., adenovirus (Tsai et al., 1998), M. gallisepticum (Murakami et al., 2002) and reovirus (Ritter et al., 1986) were previously recorded in quails. Experimental challenge of young Bobwhite quail with Cryptosporidium and reovirus showed an increase in the oocyst shedding; indicating the synergistic action of parasites and viral infections (Guy et al., 1987). Monte et al. (2018) demonstrated presence of different mixed protozoon parasites Eutrichomastix globosus, Sphaerita spp. and Blastocystis hominis in 12-week-old Japanese quails in Amazon region. An outbreak of histomoniasis caused by protozoan parasite Histomonas meleagridis was discovered in Bobwhite quails with high mortalities as well as typical cecal and liver lesions (McDougald et al., 2012). Application of sanitary measures including cleaning and disinfection of drinkers and feeders, allin/all-out policy, control of rodents and insects, avoid mixing between different ages and species, and hygienic disposal of old litter are the essential (Alan Kocan et al., 1979). Specific treatment using anthelmintic or anti protozoon drugs is very important for disease eradication.

\section{CONCLUSION}

It is very important to give attention to quail production, as it could be considered an alternative to chicken meat or egg. Good management, prevention, and control of serious diseases affecting quails are very critical to improve production and immunity.

\section{DECLARATIONS}

\section{Author's contribution}

Wafaa Abd El-Ghany collected all the data, wrote and revised the manuscript.

\section{Competing interests}

The author has no conflict of interest.

\section{REFERENCES}

Aarestrup FM, Hasman H and Jensen LB (2005). Resistant Salmonella virchow in quail products. Emerging Infectious Diseases, 11: 1984-1985. DOI: https://dx.doi.org/10.3201\%2Feid1112.010977

Adedeji AJ, Akanbi OB, Luka PD and Abdu P (2019). Natural outbreak of Marek's disease in indigenous chicken and Japanese quail (Coturnix coturnix japonica) in Jos, Plateau State, Nigeria. Open Veterinary Journal, 9 (2): 151156. DOI: http://dx.doi.org/10.4314/ovj.v9i2.10

Ahmadov EI, Topciyeva ShA, Hasanova JV and Namazova AA (2014). Effects of herbal plants on ducks and quail infected with Eimeria species. Journal of Entomology and Zoology Studies, 4(4): 1150-1152. Available at: http://www.entomoljournal.com/archives/2016/vol4issue4/PartL/4-4-32471.pdf

Akpavi V, Abdu PA, Mamman PH and Saidu L (2011). Clinicopathological features in Japanese quails (Coturnix coturnix japonica) infected with Pasteurella multocida. Sahel Journal of Veterinary Sciences, 19: 15-20.

Alan Kocan A, Hannon L and Hammond JE (1979). Some parasitic and infectious diseases of Bobwhite quail from Oklahoma. Proc Okla Academic Sciences, 59: 20-22. Available at: http://citeseerx.ist.psu.edu/viewdoc/download?doi=10.1.1.525.858\&rep=rep1 \&type $=$ pdf

Al-Nakhli HM (2005). Occurrence of paratyphoid infection among Japanese quails (Coturnix coturnix Japonica) in Saudi Arabia. Saudi Journal of Biological Science, $\quad 12$ (1): 59-66. Available at: http://www.scielo.br/scielo.php?script=sci_nlinks\&ref=000091\&pid=S1516-

Anbarasi P, Ponnudurai G, Senthilvel K, Puvarajan B and Arulmozhi A (2016). A Note on incidence of coccidiosis in Japanese quail (Coturnix coturnix japonica). Indian Veterinary Journal, 93 (02): 29-31. Available at: http://krishikosh.egranth.ac.in/handle/1/68354

Antarasena C, Sirimujalin R, Prommuang P, Blackshell SD, Promkundtod N, Prommuang P (2006). Tissue tropism of a Thailand strain of high-pathogenic avian influenza $(\mathrm{H} 5 \mathrm{~N}$ !) in tissues of naturally infected native chickens (Gallus gallus), Japanese quail (Coturnix coturnix japonica) and ducks (Anas spp.) Avian Pathology, 35 (3): 250-253. DOI: https://doi.org/10.1080/03079450600714510

Arafat N and Abbas I (2018). Coccidia of Japanese quail: From identification, prevalence, infection, and immunization. Journal of Parasitology, 104 (1): 23 30. DOI: https://doi.org/10.1645/17-109

Arenas A, Vicente S, Gomez-Villamandos LJC, Astorga R, Maldonado A and Tarradas C (1999). Outbreak of septicaemic colibacillosis in Japanese quail (Coturnix coturnix japonica). Zentralblant Veterinarmed B., 46 (6): 399-404. Available http://www.eeza.csic.es/Documentos/Publicaciones/15\%20D\%C3\%ADazS\%C3\%A1nchez\%20et\%20al.\%202012\%20EJWR.pdf

Arulmozhi A, Anbarasi P, Madheswaran R and Balasubramaniam GA (2018). Subulura brumpti and Mycoplasma infection - A concurrent outbreak in Japanese quails (Coturnix coturnix japonica). Indian Veterinary Journal, 95 (04): 46-48. Available at: https://www.researchgate.net/publication/324981640_

Arya K, Gupta R, Saxena VL. (2018). Quail survey: Elaborative information and its prospects. Research Journal of Life Science, Bioinformatics, Pharmaceutical and Chemical Sciences, 4 (4): 209. DOI: https://doi.org/10.26479/2018.0404.16

Asrani RK, Gupta RK, Sadana JR and Pandita A (1993). Experimental candidiasis in Japanese quail: pathological changes. Mycopathology, 121 (2): 83-89. DOI: https://doi.org/10.1007/BF01103575

Atalay B (2010). The effects of dietary esterified glucomannan on lipid peroxidation and some antioxidant system parameters during experimental aflatoxicosis in Japanese quails. Dicle Üniversitesi Veteriner Fakültesi Dergisi, 2: 29-33.

Babu Prasath N, Selvaraj JP and Sasikala M (2018). An outbreak of pasteurellosis in Japanese quail chicks (Coturnix coturnix japonica). Indian Journal of Animal Health, 57 (2): 189-194. Available at: http://krishikosh.egranth.ac.in/handle/1/5810099044

Bacci C, Boni E, Alpigiani I, Lanzoni E, Bonardi S and Brindani F (2012). Phenotypic and genotypic features of antibiotic resistance in Salmonella enterica isolated from chicken meat and chicken and quail carcasses. 
International Journal of Food Microbiology, 160: 16-23. DOI: https://doi.org/10.1016/j.ijfoodmicro.2012.09.014

Bagshaw C, Yates VJ, Pronovost AD and Chang PW (1980). Enhancement and inhibition of CELO virus pathogenicity in quail by avian adenovirusassociated virus. Journal of Wildlife Diseases, 16(2): 287-292. DOI: https://doi.org/10.7589/0090-3558-16.2.287

Balouria A, Deshmukh S, Banga HS, Ahmad A, Brar RS and Sodhi S (2019). Early migration pattern of Avibacterium paragallinarum in the nasal passage of experimentally infected chicken and Japanese quail by immunohistochemistry. Avian Pathology, 48 (2): 168-177. DOI: https://doi.org/10.1080/03079457.2018.1562153

Bano L, Drigo I, Macklin KS, Martin SW, Miller RS, Norton RA, Oyarzabal OA and Bilgili SF (2008). Development of a polymerase chain reaction assay for specific identification of Clostridium colinum. Avian Pathology, 37 (2): 179181. DOI: https://doi.org/10.1080/03079450801918662

Barnes HJ and Gross WB (1997). Colibacillosis. In: Calnek, B.W. Barens, H.J., Beard, C.W. McDougald, L.R. and Saif, Y.M. (EDs.), Diseases of Poultry, 10th Edition. Iowa State University Press, Ames, Iowa, pp: 131-41.

Barde IJ (2014). Haematological, serum biochemical and pathological changes in Japanese quail (Coturnix coturnix japonica) experimentally infected with Salmonella enterica serovar Gallinarum. Master of Science of Ahmadu Bello University, Zaria, Nigeria. Available at: http://kubanni.abu.edu.ng/jspui/bitstream/123456789/5412/1/HAEMATOLO GICAL $\% 2 C \% 20$ SERUM $\% 20$

Beernaert LA, Pasmans F, van Waeyenberghe L, Haesebrouck F and Martel A (2010). Aspergillosis infection in birds: A review. Avian Pathology, 39: 325331. DOI: https://doi.org/10.1080/03079457.2010.506210

Beltran-Alcrudo D, Cardona C, McLellan L, Reimers N and Charlton B (2008). A persistent outbreak of ulcerative enteritis in Bobwhite quail (Colinus virginianus). Avian Diseases, 52(3):531-536. DOI: http://dx.doi.org/10.1637/8195-121307-Case

Berkhoff GA (1975). Ulcerative enteritis-clostridial antigens. American Journal of Veterinary Research, 36: 583-585. Available at: http://citeseerx.ist.psu.edu/viewdoc/download?doi=10.1.1.1020.3417\&rep=re p1\&type $=$ pdf

Berkhoff HA (1985). Clostridium colinum sp. nov., nom. rev., the causative agent of ulcerative enteritis (quail disease) in quail, chickens, and pheasants. International Journal of Systemic Bacteriology, 35: 155-159. Available at: https://www.microbiologyresearch.org/content/journal/ijsem/10.1099/002077 13-35-2-155 ?crawler=true \& mimetype=application/pdf

Berkhoff GA and Kanitz CL (1976). Fluorescent antibody test in diagnosis of ulcerative enteritis. Avian Diseases, 20: 525-533. DOI: https://doi.org/10.2307/1589385

Bermudez AJ, Munger LL and Ley DH (1997). Pasteurellosis in Bobwhite quails. Avian Diseases, 35: 618-620. Available at: https://www.ncbi.nlm.nih.gov/pubmed/1953585

Bertran K, Dolz R, Busquets N, Gamino V, Vergara-Alert J, Chaves AJ, Ramis A, Abad XF, Höfle U and Majó N (2013). Pathobiology and transmission of highly and low pathogenic avian influenza viruses in European quail (Coturnix coturnix). Veterinary Research, 44 (1): 23. DOI: https://dx.doi.org/10.1186\%2F1297-9716-44-23

Basheer DA, Jayaraman S, Prasath B and Sasikala M (2017). Pathomorphology of aspergillosis in a Japanese quail. Indian Veterinary Journal, 94 (10): 85-86. Available

https://www.researchgate.net/publication/320865210_Pathomorphology_of_a spergillosis_in_a_Japanese_quail

Blackall PJ and Hinz K (2008). Infectious Coryza and Related Disease. In: Pattison, M., Mc Mullin, P.F, Bradbury, J.M., Alexander, D.J. Poultry Disease. 6th ed. London: WB Saunders. Company; pp. 155-159.

Blackall PJ and Yamamoto R (1989). In: Isolation and Identification of Avian Pathogens. 3rd Edition. Iowa: American Association of Avian Pathogens, Inc.; Infectious Coryza; pp. 27-31.

Bolte AL, Meurer J and Kaleta EF (1999). Avian host spectrum of avipoxviruses. Avian Pathology, 28: 415-432. Available at: https://www.ncbi.nlm.nih.gov/pubmed/26911595

Borah MK, Jangir BL, Raut SS, Gogo R and Sharma GD (2010). Aspergillosis in Japanese quail (Coturnix coturnix japonica). Indian Journal of Veterinary Pathology, $34 \quad$ (2): 203-204. Available at: ndianjournals.com/ijor.asp ? target $=$ ijor:ijvp $\&$ volume $=34 \&$ issue $=2 \&$ article $=0$ 29

Brown J1, Dawe DL, Killingsworth R and Davis RB (1970). Antibiotic treatment of ulcerative enteritis of Bobwhite quail. Journal of Wildlife Diseases, 6 (1): 8 12. DOI: https://doi.org/10.7589/0090-3558-6.1.8
Burns KE, Otalora R, Glisson JR and Hofacre CL (2003). Cellulitis in Japanese quail (Coturnix coturnix japonica). Avian Diseases, 47 (1): 211-214. DOI https://doi.org/10.1637/0005-2086(2003)047

Carlson UC, Seawright GL and Rettit JR (1974). Reticuloendotheliosis in Japanese quail. Avian Pathology, 3: 169-175. Available at: https://www.tandfonline.com/doi/pdf/10.1080/03079459008418661

Chadran NDJ, Prabakar TG, Albert A, David BP and Venkatesan RA (1995). Pasteurellosis in Japanese quail (Coturnix coturnix japonica). Indian Veterinary Journal, 72: 876-877.

Chandrasekaran S and Aziz HA (1989). Outbreak of Newcastle disease in Japanese quail. Journal of Veterinary Malay, 1: 9-15. Available at https://pdfs.semanticscholar.org/e693/54cba175d3b4a393646f356b62460524 3f65.pdf

Chang C and Hamilton PB (1982): Experimental aflatoxicosis in young Japanese quail, Poultry Science, 61: 869- 874. DOI: https://doi.org/10.3382/ps.0610869

Chauhan HV and Roy SS (2008). Poultry Diseases and Treatment, New Age International (P) Limited, New Delhi, India.

Citil M, Karapehliv M, Tuzcu M, Dogan A, Uzla E, Attack E, Kanici A. and Uzun M (2007). Effect of L-carnitine supplementation on biochemical, haematological and pathological parameters of quails (Coturnic coturnix japonica) during chronic aflatoxicosis. The Journal of Kafkas Üniversites Veteriner Fakültesi Dergisi, 13 (1): 75-85.

Cooper KK, Songer JG and Uzal FA (2013). Diagnosing clostridial enteric disease in poultry. Journal of Veterinary Diagnostic Investigation, 25, 314-327. DOI: https://doi.org/10.1177\%2F1040638713483468

Crawford JA, Oates RM and Helfer DH (1979). Avian pox in California quail from Oregon. Journal of Wildlife Diseases, 15: 447-449. DOI https://doi.org/10.7589/0090-3558-15.3.447

Crespo R, Franca M and Shivaprasad HL (2013). Ulcerative enteritis-like disease associated with Clostridium sordellii in quail. Avian Diseases, 57: 698-702. DOI: https://doi.org/10.1637/10485-010813-Case.1

Cundy KR (1965). Susceptibility of Japanese quail (Coturnix coturnix japonica) to experimental infection with Haemophilus gallinarum. Avian Diseases, 10 272-283. Available at: https://www.medigraphic.com/cgi$\mathrm{bin} / \mathrm{new} /$ resumenI.cgi?IDARTICULO $=6883$

Dash BB and Pradhan HK (1990). Egg drop syndrome-76 (EDS-76) in quail: A preliminary report. Proceedings of the 13 Annual Conference and National Symposium of Indian Poultry Science Association, December 20-22, Bombay, India. pp. 130

Dash BB and Pradhan, HK (1992). Outbreaks of egg drop syndrome due to EDS-67 virus in quail (Coturnix coturnix japonica). Veterinary Record, 131: 264-265. DOI: https://www.ncbi.nlm.nih.gov/pubmed/132930410.1136/vr.131.12.264

Da Silva PL, Coelho HE, Ribeiro SC and Oliveira PR (1989). Occurrence of coligranulomatosis in Coturnix quail in Uberlandia, Minas Gerais, Brazil. Avian Diseases, 33: 590-593. Available at https://www.ncbi.nlm.nih.gov/pubmed/2673192

Davidson WR, Kellogg FE and Doster GL (1980). An epornitic of avian pox in wild Bobwhite quail. Journal of Wildlife Diseases, 16: 293-298. Available at: https://dergipark.org.tr/tr/pub/tbtkveterinary/issue/12545/151389

Dhama K, Barathidasan R, Tiwari R and Singh SD (2012). Aspergillosis: An important fungal disease of poultry and other birds. Poultry World, 9: 7-9.

Dhama K, Chakraborty S, Verma AK et al. (2013) Fungal/mycotic diseases of poultry-diagnosis, treatment and control: A Review. Pakistan Journal of Biological Sciences, 16: 1626-1640. Available at: https://scialert.net/abstract/?doi=pjbs.2013.1626.1640

Dho-Moulin M and Fairbrother JM (1999). Avian pathogenic Escherichia coli (APEC). Veterinary Research, 30: 299-316. Available at: https://www.ncbi.nlm.nih.gov/pubmed/10367360

DuBose RT, Grumbles LC and Flowers AI (1958). The isolation of nonbacterial agent from quail with a respiratory disease. Poultry Science, 37: 654-658. DOI: https://doi.org/10.3382/ps.0370654

Dutton RL, Kenzy SG and Becker WA (1973). Marek's disease in the Japanese quail (Coturnix coturnix japonica), Poultry Science, 52: 139-143. DOI: https://doi.org/10.3382/ps.0520139

Dyar PM, Fletcher OJ and Page, RK (1984). Aspergillosis in turkeys associated with use of contaminated litter. Avian Diseases, 28: 250-255. Available at: https://www.jstor.org/stable/1590149

Edris AM, Shaltout FA and Arab WS (2004). Bacterial evaluation of quail meat Benha Veterinary Medical Journal, 16 (1): 1-14. 
El-Morsy MA, Abou El-Azm KI and Awad SS. (2016). Efficacy of some anticoccidial drugs on experimentally induced cecal coccidiosis (E.tsunodai) in Japanese quails. Egyptian Journal of Veterinary Science, 47 (2): 165-177. Available https://ejvs.journals.ekb.eg/article_3591_9c43a9c2b7f90e606bc0a82acb6d1c 63.pdf

Eraslan G, Liman B, Guclu BK, Ata-sever A, Koc AN and Beyaz L (2004). Evaluation of aflatoxin toxicity in Japanese quails given various doses of hydrated sodium calcium aluminosilicate. Bulletin of the Veterinary Institute in Pulawy, 48: 511-517.

El-Tarabili MM, El-Shahiedy MS, Hammouda MS et al. (2009). Natural and experimental infections of quails (Couturnix couturnix japonica) with Newcastle disease virus. Suez Canal Veterinary Medical Journal, 16: 67-80. Available

https://scholar.google.com/scholar_lookup?hl=en\&publication_year=2009\&p ages $=67-80 \&$ author $=\mathrm{MM}+\mathrm{El}-$ Tarabili\&author $=\mathrm{MS}+\mathrm{El}-$

Shahiedy\&author=MS+Hammouda\&title=Natur

Erbeck DH and Nun SA (1999). Chlamydiosis in pen-raised Bobwhite quail (Colinus virginianus) and Chukar Partridge (Alectoris chukar) with high mortality. Avian Diseases, 43: 798-803. Available at: https://www.ncbi.nlm.nih.gov/pubmed/10611999

Erdogrul O, Ozkan N and Cakiroglu E (2002). Salmonella enteritidis in quail eggs. Turkish Journal of Veterinary Animal Science, 26: 321-323.

Ficken MD and Wage DP (1997). Necrotic enteritis. In: Calnek, B.W. Barens, H.J., Beard, C.W. McDougald, L.R. and Saif, Y.M. (EDs.), Diseases of Poultry, 10th Edition. Iowa State University Press, Ames, Iowa, pp. 261-64.

Freitas Neto OC de, Angela HL da, Soares NM, Guastalli EAL, Almeida AM de and Berchieri Junior A (2013). Salmonella spp. in meat-type quails (Coturnix coturnix coturnix) in the State of São Paulo, Brazil. Brazilian Journal of Poultry Science, 15 (3): 169-286. DOI: http://dx.doi.org/10.1590/S1516-

Fujimoto Y, Mikami T, Narita M and Okada, K (1975). Pathological studies of Marek's disease in Japanese quail. Japanese Journal of Veterinary Research, 23: 119-124. Available at: http://hdl.handle.net/2115/2069

Gesek M, Welenc J, Otrocka-Domagała TZI, Paździor K and Rotkiewicz A (2014). Pathomorphological changes in the alimentary system of Japanese quails naturally infected with Eimeria tsunodai. Bulletin Veterinary Institute Pulawy, 58: 41-45. DOI: https://doi.org/10.2478/bvip-2014-0007

Ghildyal N, Schnitzlein WM and Tripathy DN (1989). Genetic and antigenic differences between fowl pox and quail poxviruses. Archive Virology, 106: 85-92. DOI: https://doi.org/10.1007/bf01311040

Glisson JR, Cheng IH, Rowland GN and Stewart RG (1989). Pasteurella multocida infection in Japanese quail (Coturnix coturnix japonica). Avian Diseases, 33 (4): 820-822. Available at: https://www.jstor.org/stable/1591167

Goto Y, Nakura R, Nasu T, Sawada T and Shinjo T (2001). Isolation of Pasteurella multocida during an outbreak of infectious septicaemia in Japanese quail (Coturnix coturnix Japonica). Journal of Veterinary Medical Sciences, 63 (9): 1055-1056. DOI: https://doi.org/10.1292/jvms.63.1055

Gowthaman V, Singh SD, Barathidasan R, Ayanur A and Dhama K (2013). Natural outbreak of Newcastle disease in turkeys and Japanese quails housed along with chicken in a multi-species poultry farm in Northern India. Advances in Animal Veterinary Science, 1 (3S): 17-20. Available at: https://scholar.google.com/scholar_lookup?hl=en\&publication_year=2013\&p ages $=1720 \&$ issue $=3$ S \&author $=\mathrm{V}+$ Gowthaman $\&$ author $=\mathrm{SD}+$ Singh \&author $=$ $\mathrm{R}+$ Barathidasan \& title $=\mathrm{Natural}+$ outbreak + of + Newcastle + disease + in +

Grewal GS, Singh A, Singh B and Oberoi MS (1994). Inclusion body hepatitis in Japanese quail (Coturnix coturnix japonica). Indian Journal of Animal Science, 64: 665-667. Available at: https://www.researchgate.net/publication/281347416_Inclusion_body_hepatit is_in_Japanese_quails_Coturnix_coturnix_japonica

Gumussoy KS, Uyanik F, Atasever A and Cam Y (2004). Experimental Aspergillus fumigatus infection in quails and results of treatment with itraconazole. Journal of Veterinary Medicine B, Infectious Diseases of Veterinary Public Health, 51 (1):34-38. DOI: https://doi.org/10.1046/j.1439-0450.2003.00720.x

Guan Y, Shortridge KF, Krauss S, Chin PS, Dyrting KC, Ellis TM, Webster RG and Peiris M (2000). H9N2 influenza viruses possessing H5N1-like internal genomes continue to circulate in poultry in southeastern China. Journal of Virology, 74: 9372-9380. DOI: https://doi.org/10.1128/jvi.74.20.93729380.2000

Gülbahar MY, Cabalar M and Boynukara B (2005). Avipoxvirus infection in quails. Turkish Journal of Veterinary Animal Science, 29: 449-454. Available at: https://pdfs.semanticscholar.org/bab5/a4633daad86f3d31070aea449c443762e d51.pdf
Guo YJ, Krauss S, Senne DA, Mo IP, Lo KS, Xiong XP, Norwood M, Shortridge KF, Webster RG and Guan Y (2000). Characterization of the pathogenicity of members of the newly established H9N2 influenza virus lineages in Asian Virology, 267: 279-288. Available at: https://www.ncbi.nlm.nih.gov/pubmed/10662623

Guy JS, Levy MG, Ley DH, Barnes HJ and Gerig TM (1987). Experimental reproduction of enteritis in Bobwhite quail (Colinus virginianus) with Cryptosporidium and reovirus. Avian Diseases, 31: 713-722. DOI: Available at: https://www.jstor.org/stable/1591021

Hamed DM and Hassan AMA (2013). Acids supplementation to drinking water and their effects on Japanese quails experimentally challenged with Salmonella Enteritidis. Research in Zoology, 3(1): 15-22. Available at: http://article.sapub.org/10.5923.j.zoology.20130301.03.html

Hamad MA, Al-Aalim AM, Al-Dabbagh SYA and Ali HH (2012). Detection of organ bacterial load in quails. Iraqi Journal of Veterinary Science, 26 (2): 47 51. Available at: http://citeseerx.ist.psu.edu/viewdoc/download?doi=10.1.1.428.6591\&rep=rep $1 \&$ type $=$ pdf

Hassan AM, Mohammed DA, Hussein KN and Hussen SH (2017). Comparison among three lines of quail for egg quality characters. Science Journal of University of Zakho, 5 (4): 296-300.

Hinshaw WR and Emlen JT (1943). Pasteurellosis in California Valley quail. Cornell Veterinary, 33: 351-353. Available at: http://www.scielo.br/scielo.php?script=sci_nlinks\&ref=000066\&pid=S1517-

$8382201300010002300002 \& \operatorname{lng}=$ en

Hoerr FJ, Current W and Haynes TB (1984). Intestinal cryptosporidiosis in quail Journal of American Veterinary Medical Association, 185: 342. Available at: https://www.tandfonline.com/doi/pdf/10.1080/030794502201633

Hoerr FJ, Current WL, Haynes TB (1986). Fatal cryptosporidiosis in quail. Avian Diseases, 30: 421-25. Available at: https://www.ncbi.nlm.nih.gov/pubmed/3729889

Hulse-Post DJ, Sturm-Ramirez KM, Humberd J, Seiler P, Govorkova EA, Krauss S, Scholtissek C, Puthavathana P, Buranathai C, Nguyen TD et al. (2005). Role of domestic ducks in the propagation and biological evolution of highly pathogenic $\mathrm{H} 5 \mathrm{~N} 1$ influenza viruses in Asia. Proceedings of the National Academy of Sciences, USA, 102: 10682-10687.

Imai K, Yuasa N, Kobayashp S, Nakamura K, Tsukamoto K. and Hihara H (1990). Isolation of Marek's disease virus from Japanese quail with lymphoproliferative disease. Avian Pathology, 19: 119-129. DOI: https://doi.org/10.1080/03079459008418661

Indriani R and Dharmayanti NLPI (2016). Vaccination of quails with bivalent inactivated $\mathrm{H} 5 \mathrm{~N} 1 \mathrm{AI}$ vaccine (clades 2.1.3 and 2.3.2) at laboratory scale. Proceedings of International Seminar on Livestock Production and Veterinary Technology, Indonesia, pp. 441-448. DOI: http://dx.doi.org/10.14334/Proc.Intsem.LPVT-2016-p.441-448

Islam HA, Ito J, Tanakuwa H, Takada A, Itrakura C and Kida H (1994). Acquisition of pathogenicity of Newcastle disease virus isolated from Japanese quail by intracerebral passage in chickens. Japanese Journal of Veterinary Research, 42: 147-156. Available at: https://www.ncbi.nlm.nih.gov/pubmed/7745878

Islam MR, Das BC, Hossain K, Lucky NS and Mostafa MG (2003). A study on the occurrence of poultry diseases in Sylhet region of Bangladesh. International Journal of Poultry Science, 2: 354-356. DOI http://dx.doi.org/10.3923/ijps.2003.354.356

Islam Md T, Talukder AK, Rahman Md A, Haider Md G, Abu Nasar Md and Aminoor R (2016). Incidence of diseases in Japanese quail (Coturnix coturnix japonica) with special reference to bacterial and viral diseases in some selected areas of Bangladesh. Asian Australian Journal of Bioscience $\begin{array}{lllll}\text { and } & \text { Biotechnology, } & 1 & \text { (3): } & 410-418 .\end{array}$ at:https://www.ebupress.com/journal/aajbb/wpcontent/uploads/sites/3/2016/10/55.pdf

Ito H, Skoda S, Kobayashi S, Sugiyama H and Masanori N (1990). Colibacillosis of Japanese quail (Coturnix coturnix japonica) occurring in Higashimikawa District. Journal of Japanese Veterinary Medical Association, 43: 661-665. DOI: https://doi.org/10.12935/jvma1951.43.661

Jack SW and Reed WM (1990). Pathology of experimentally induced quail bronchitis. Avian Diseases, 34: 44-51. DOI: 10.2307/1591332

Jack SW, Reed WM and Bryan TA (1987). Inclusion body hepatitis in Bobwhite quail (Colinus virginianus). Avian Diseases, 31: 661-665. Available at: https:// www.jstor.org/stable/1590757

Jahan S, Zihadi MdAH, Nazir NHKHM, Islam SMd, Rahman BMd and Rahman M (2018). Molecular detection and antibiogram of Salmonella spp. from apparently healthy Japanese quails of three different quail farms in 
Mymensingh. Journal of Advanced Veterinary Animal Research, 5 (1): 6066. Available at: https://www.scopemed.org/?mno=1004506

Jeong OM, Kim MC, Kim MJ, Kang HM, Kim HR, Kim YJ, Joh SJ, Kwon JH and Lee YJ (2009). Experimental infection of chickens, ducks and quails with the highly pathogenic H5N1 avian influenza virus. Journal of Veterinary Science, 10: 53-60: DOI: https://doi.org/10.4142/jvs.2009.10.1.53

Jones JE, Hughes BL and Mulliken WE (1976). Use of tylosin to prevent early mortality in Bobwhite quail. Poultry Science, 55 (3): 1122-1123. DOI: https://doi.org/10.3382/ps.0551122

Kaleta EF and Baldauf C (1988). Newcastle disease in free-living and pet birds. In: Newcastle disease. Alexander D.J. (Ed). Norwell, M.A., Kluwer Academic Publishing, pp: 197-246.

Kasmani FB, Karimi F, Torshizi MA, Allameh A and Shariatmadari, F (2012). A Novel aflatoxin-binding Bacillus probiotic: performance, serum biochemistry, and immunological parameters in Japanese quail. Poultry Science, 91: 1846-1853. DOI: https://doi.org/10.3382/ps.2011-01830

Kasmani FB, Torshizi MAK and Mehri M. (2018). Effect of Brevibacillus laterosporus probiotic on hematology, internal organs, meat peroxidation and ileal microflora in Japanese quails fed aflatoxin B1. Journal of Agricultural Science and Technology, 20 (3): 459-468. Available at: https://www.researchgate.net/publication/324861162_

Kataria JM, Swain P, Dash BB and Verma KC (1991). Egg drop syndrome-76 (EDS-76) virus infection in Japanese quail. Proceedings in the Souvenir $12^{\text {th }}$ Annual Conference of IAVMI and National Symposium on Important Infectious Diseases of Livestock and Poultry, September $12-14^{\text {th }}$, Tirupati, India, p. 6.

Kenzy SG and Cho BR (1969). Transmission of classical Marek's disease by affected and carrier birds. Avian Diseases, 13: 211-214. Available at: https://www.ncbi.nlm.nih.gov/pubmed/4304671

Khan MA, Asrani RK, Iqbal A, Patil RD, Rottinghaus GE and Ledoux DR (2013). Fumonisin B1 and ochratoxin A nephrotoxicity in Japanese quail: an ultrastructural assessment. Comparative Clinical Pathology, 22: 835-843. DOI: https://doi.org/10.1007/s00580-012-1486-6

Khare ML, Grun J and Adams EV (1975). Marek's disease in Japanese quail - a pathological, virological and serological study. Poultry Science, 54: 20662081. DOI: https://doi.org/10.3382/ps.0542066

King DJ, Pursglove SR Jr and Davidson WR (1981). Adenovirus isolation and serology from wild Bobwhite quails. Avian Diseases, 25: 678-682. Available at: https://link.springer.com/article/10.1023/A:1020299700907

Kobayushi SK and Mikami T (1986). A study of Marek's disease in Japanese quails vaccinated with herpesvirus of turkeys. Avian Diseases, 30: 816-819. Available at: https://www.ncbi.nlm.nih.gov/pubmed/3814019

Kumar AA, Shivachandra SB, Biswas A, Singh VP, Singh VP and Srivastava SK (2004). Prevalent serotypes of Pasteurella multocida isolated from different animal and avian species in India. Veterinary Research Communication, 28 (8): 657-667. DOI: https://doi.org/10.1023/B:VERC.0000045959.36513.e9.

Kunkle RA (2003). Fungal Infections. In: Diseases of Poultry, Saif, Y.M. (Ed.). 11th Edition. Wiley-Blackwell, Iowa State University Press, Ames, IA., USA.

Lee YJ, Choi YK, Kim YJ, Song MS, Jeong OM, Lee EK, Jeon WJ, Jeong W, Joh SJ, Choi KS. et al. (2008). Highly pathogenic avian influenza virus (H5N1) in domestic poultry and relationship with migratory birds, South Korea. Emerging Infectious Diseases, 14: 487-490. DOI: https://dx.doi.org/10.3201\%2Feid1403.070767

Lima FS, Santin E, Paulillo AC and Doretto JL (2004). Evaluation of different programs of Newcastle disease vaccination in Japanese quail (Coturnix coturnix japonica). International Journal of Poultry Science, 3: 354-356. Available

http://citeseerx.ist.psu.edu/viewdoc/download?doi=10.1.1.509.9427\&rep=rep $1 \&$ type $=$ pdf

Lindsay DS, Blagburn BL, Hoerr FJ and Smith PC (1991). Cryptosporidiosis in zoo and pet birds. Journal of Protozoon, 38: 180S-181S. Available at:https://www.ncbi.nlm.nih.gov/pubmed/1818158

Lozano MC, Diaz GJ. (2006). Microsomal and cytosolic biotransformation of aflatoxin B1 in four poultry species. British Poultry Science, 47: 734-741. DOI: https://doi.org/10.1080/00071660601084390

McDougald LR1, Abraham M and Beckstead RB (2012). An outbreak of blackhead disease (Histomonas meleagridis) in farm-reared Bobwhite quail (Colinus virginianus). Avian Diseases, 56 (4): 754-756. DOI: https://doi.org/10.1637/10140-032212-Case.1

Madden DL, Henderson WH and Moses HE (1967). Case report: Isolation of Mycoplasma gallisepticum from Bobwhite quail(Colinus virginianus). Avian
Diseases, 11: 378-380 Available at: https://www.ncbi.nlm.nih.gov/pubmed/6069465

Manafi M (2018). Toxicity of aflatoxin B1 on laying Japanese quails (Coturnix coturnixjaponica), Journal of Applied Animal Research, 46 (1): 953-959. DOI: https://doi.org/10.1080/09712119.2018.1436550

Manickam R, Masilamoni S, Ronald B and Ponnusamy P (2017). Isolation and detection of bacterial species from visceral organs of quails. International Journal of Sciences and Environmental Technology, 6 (2): 1153-1160. Available at: http://krishikosh.egranth.ac.in/handle/1/5810030222

Mazlan LF, Bachek NF, Mahamud SNA, Idris LH, Wei TS, Omar AR and Noor MHM (2017). The positive expression of genotype VII Newcastle disease virus (Malaysian isolate) in Japanese quails (Coturnix coturnix japonica), $\begin{array}{llll}\text { Veterinary } & \text { World, } & 10(5): & 542-548 .\end{array}$ http://www.veterinaryworld.org/Vol.10/May-2017/13.html

Mera UM, Musa U and Abubakar AU (2017). Isolation of Escherichia coli and Salmonella spp from Japanese quail (Coturnix coturnix japonica) raw eggs from selected farms in Sokoto metropolis, Nigeria. Scholars Journal of Agriculture and Veterinary Science, 4 (7): 282-285. Available at: http://saspjournals.com/wp-content/uploads/2017/08/SJAVS-47282-285.pdf

Miguel B, Wang C, Maslin WR, Keirs RW and Glisson JR (1998). Subacute to chronic fowl cholera in a flock of Pharaoh breeder quail. Avian Diseases, 42: 204-208. Available at: https://www.jstor.org/stable/1592598

Migliorini MJ, Da Silva AS, Santurio JM, Bottari NB et al. (2017). The Protective effects of an adsorbent against oxidative stress in quails fed aflatoxincontaminated diet. Acta Scientiae Veterinariae, 45 (1): $1473 . \quad$ Available at:https://seer.ufrgs.br/ActaScientiaeVeterinariae/article/view/80468

Mikami T, Onuma M, Hayashi TTA, Narita M, Okada K and Fujimoto Y (1975). Pathogenic and serologic studies of Japanese quail infected with JM strain of Marek's disease herpesvirus. Journal of National Cancer Institute, 54: 607$614 . \quad$ Available https://www.tandfonline.com/doi/pdf/10.1080/03079459008418661

Mohamed MA and Abdel Hafez MS (2016). The susceptibility of Japanese quails to the infection with chicken originated Newcastle disease virus. Journal of Advanced Veterinary Research, 6 (1): 37-43. Available at: https://advetresearch.com/index.php/AVR/article/view/35

Mohapatra N, Kataria JM, Chakraborty S and Dhama K (2014). Egg drop syndrome-76 (EDS-76) in Japanese quails (Coturnix coturnix japonica): An experimental study revealing pathology, effect on egg production/quality and immune responses. Pakistan Journal of Biological Science, 17(6): 821-828. Available at: https://scialert.net/fulltextmobile/?doi=pjbs.2014.821.828

Shoushtari AH, Toroghi R, Pourbakhsh, SA, Gharahkhani P, Momayez R and Banani $M$ (2007). Isolation and pathogenicity identification of avian paramyxovirus serotype 1 (Newcastle disease) virus from a Japanese quail flock in Iran. Archives of Razi Institute, 62 (1): 39-44. DOI: https://dx.doi.org/10.22092/ari.2007.103782

Monte GLS, Cavalcante DG and Oliveira JBS (2018): Parasitic profiling of Japanese quails (Coturnix japonica) on two farms with conventional production system in the Amazon region. Pesquisa Veterinária Brasileira 38(5):847-851. DOI:

http://dx.doi.org/10.1590/1678-5150-pvb-5274.

Moscovici C and Macintyre EH (1966). Effect of avian myeloblastosis virus in the Japanese quail. Journal of Bacteriology, 92: 1141-1149. Available at: https://europepmc.org/abstract/med/4288797

Murakami AE (1991). Níveis de proteína e energia em dietas de codornas japonesas (Coturnix coturnix japonica) nas fases de crescimento e postura [tese]. Jaboticabal (SP): Universidade Estadual Paulista; 1991. Available at: http://www.scielo.br/scielo.php?script=sci_arttext\&pid=S151635982002000700019

Murakami S, Miyama M, Ogawa A, Shimada J and Nakane T (2002). Occurrence of conjunctivitis, sinusitis and upper region tracheitis in Japanese quail (Coturnix coturnix japonica), possibly caused by Mycoplasma gallisepticum accompanied by Cryptosporidium sp. infection. Avian Pathology, 31 (4): 363-370. DOI: https://doi.org/10.1080/030794502201633.

Mwankon ES, Odugbo MO, Jwander LD, Olabode V, Ekundayo SO, Musa U, Spencer TH, Isa SI, Kaikabo A and Simon BS (2009). Investigations on the carrier rate of Pasteurella multocida in black rats (Rattus rattus) in a commercial quail farm. African Journal of Clinical and Experimental Microbiology, 10: 2-9.

Myint A and Carter GR (1988). Fowl cholera in quail in Burma. Tropical Animal Health Production, 20: 35-36. DOI: https://doi.org/10.1007/BF02239642 
Naeem K, Ullah A, Manvell RJ and Alexander DJ (1999). Avian influenza A subtype H9N2 in poultry in Pakistan. Veterinary Record, 145: 560. DOI: https://doi.org/10.1136/vr.145.19.560

Nain S and Smits JEG (2011). Validation of a disease model in Japanese quail (Coturnix coturnix japonica) with the use of Escherichia coli serogroup O2 isolated from a turkey. Canadian Journal of Veterinary Research, 75: 171175. Available at: https://www.ncbi.nlm.nih.gov/pmc/articles/PMC3122969/

Nardelli L, Rinaldi A, Pereira HG and Mandelli G (1970). Influenza virus infections in Japanese quails. Archive of Experimental Veterinary Medicine, 24: 231Available

https://scholar.google.com/scholar?hl=en\&as_sdt=0,5\&q=Nardelli,+L.,+A.+ Rinaldi,+H.+G.+Pereira,+and+G.+Mandelli.+1970.+Influenza+virus+infectio ns+in+Japanese+quails.+Arch.+Exp.+Veterinary+Med.+24\%3A231249.+(In+German.)

Nascimento ER, Polo PA, Nascimento MGF and Lignon G (1997). Isolamento de Mycoplasma gallisepticum e M. synoviae de codornas (Coturnix coturnis japonica). In: 25 Congresso Brasileiro de Medicina Veterinária; Gramado, Rio Grande do Sul. Brasil. p.171

Nascimento MGF and Nascimento ER (1986). Infectious sinusitis in coturnix quails in Brazil. Avian Diseases, 30: 228-230. Available at: https://www.jstor.org/stable/1590641

Nascimento MGF, Polo PA, Nascimento ER and Lignon GB. (1998). Search for Mycoplasma gallisepticum and M. synoviae in an outbreak of sinusitis and arthritis in quails. In: Proceedings of the $47^{\circ}$ Western Poultry Disease Conference; Sacramento, Califórnia. USA. pp. 83-84.

Naveen KA and Arun CS (1992). Diseases of quails. Poultry Adviser, 25: 43-48. Available https://pdfs.semanticscholar.org/3edc/64a97dafeb152720c3755d637a24f9555 ca2.pdf

Odugbo MO, Muhammad M, Musa U, Suleiman AB, Ekundayo SO and Ogunjumo SO (2004). Pasteurellosis in Japanese quail (Coturnix coturnix japonica) caused by Pasteurella multocida A: 4. Veterinary Record, 155: 90-91. DOI: http://dx.doi.org/10.1136/vr.155.3.90

Ogido R, Oliveira CAF, Ledoux DR, Rottinghaus GE, Correa B, Butkeraitis P, Reis TA, Goncales E and Albuquerque R (2004). Effects of prolonged administration of aflatoxin B1 and fumonisin B1 in laying Japanese quail. Poultry Science, 83: 1953-1958. DOI: https://doi.org/10.1093/ps/83.12.1953

Oladele SB, Enoch I, Lawal S and Ibu OJ (2008). Clinico-pathological features of Newcastle disease in Japanese quails (Coturnix coturnix japonica) infected with Newcastle disease virus Kudu 113 strain. International Journal of $\begin{array}{lllll}\text { Poultry } & \text { Science, } & 7 & \text { (2): } & \text { 165-168. }\end{array}$ http://dx.doi.org/10.3923/ijps.2008.165.168

Olsen ND (1950). A respiratory disease (bronchitis) of quail caused by a virus. Proceedings of 54th Annual Meeting, US Livestock Sanitary Association, Arizona, U.S.

Oliveira CAF, Rosmaninho JF, Butkeraitis P, Correa B, Reis TA, Guerra JL, Albuquerque R and Moro MEG (2002). Effect of low levels of dietary aflatoxin B1 on laying Japanese quail. Poultry Science, 81: 976-980. DOI: https://doi.org/10.1093/ps/81.7.976

Oguz H and Parlat SS (2004). Effects of dietary mannanoligosaccharide on performance of Japanese quail affected by aflatoxicosis. South African Journal of Animal Science, 34: 144-148. DOI:http://dx.doi.org/10.4314/sajas.v34i3.3957

Palanisamy S and Bamaiyi PH (2015). Isolation and antibiogram of Salmonella spp. from quails in a farm from Kelantan, Malaysia. Journal of Veterinary Advances, $\quad 5 \quad$ (12): $1191-1198 . \quad$ DOI: https://doi.org/10.5455/jva.20151214015140

Panigrahy J and Glass N (1982). Outbreak of fowl cholera in quails. Avian Diseases, 26: 200-203. Available at: https://www.ncbi.nlm.nih.gov/pubmed/7092741

Parlat SS, özcan M and Oguz H (2001). Biological suppression of aflatoxicosis in Japanese quail (Coturnix coturnix japonica) by dietary addition of yeast (Saccharomyces cerevisiae). Research in Veterinary Science, 71 (3): 207211. DOI: https://doi.org/10.1053/rvsc.2001.0512

Patial V, Asrani RK and Patil RD (2013a). Nephrotoxicity of ochratoxin-A in quail: A clinico-pathological study. Journal of Poultry Science Technology, 1: 7-12. Available https://pdfs.semanticscholar.org/4fba/cc4155cc9a20b2dca17246677eb0708b4 8c7.pdf

Patial V, Asrani RK, Patil RD, Ledoux DR and Rottinghaus GE (2013b). Pathology of ochratoxin A induced nephrotoxicity in Japanese quail and its protection by seabuckthorn (Hippophae rhamnoides L.). Avian Diseases, 57: 767-779. DOI: https://doi.org/10.1637/10549-040913-Reg.1
Paulillo AC (1989). Avaliação da resposta imune e da performance zootécnica de poedeiras vacinadas experimentalmente contra a doença de Newcastle. Tese de Livre Docência em Ornitopatologia, Faculdade de Ciências Agrárias e Veterinárias, Jaboticabal, Universidade Estadual Paulista, p.116

Paulillo AC, Schmidt EMS, Denadai J, Lima FS and Junior LD (2009). Experimental vaccination against Newcastle disease in Japanese quails ( Coturnix coturnix japonica ): clinical and immunological parameters. International Journal of Poultry Science, 8(1): 52-54. Available at: https://scialert.net/abstract/?doi=ijps.2009.52.54

Perez DR, Lim W, Seiler JP, Yi G, Peiris M, Shortridge KF and Webster RG (2003). Role of quail in the interspecies transmission of H9 influenza A viruses: molecular changes on HA that correspond to adaptation from ducks to chickens. Journal of Virology, 77: 3148-3156. Available at: https://www.ncbi.nlm.nih.gov/pubmed/12584339

Poonacha KB and Wilson M (1981). Avian pox in pen-raised Bobwhite quail. Journal of American Veterinary Medical Association, 179: 1264-1265. Available at: https://www.ncbi.nlm.nih.gov/pubmed/6276350

Powell PC and Rennie M (1984). The expression of Marek's disease tumourassociated surface antigen in various species. Avian Pathology, 13: 345-349. DOI: https://doi.org/10.1080/03079458408418537

Pradhan HK, Mohanty GC and Mukit A (1985). Marek's disease in Japanese quails (Cotumix cotumix japonica): a study of natural cases. Avian Diseases, 29 : 575-582. Available at: https://www.ncbi.nlm.nih.gov/pubmed/3000332

Prescott JF (2016). Disease caused by Clostridium colinum: ulcerative enteritis of poultry and other avian species. Clostridial Diseases of Animals. pp. 331-332.

Prior MG, Sisodia CS and O’Neil JB (1976). Acute oral ochratoxicosis in day old White Legharns, turkeys and Japanese quail. Poultry Science, 55: 786-790. DOI: https://doi.org/10.3382/ps.0550786

Promkuntod N, Antarasena C, Prommuang P and Thiptara A (2003). Experimental assessment of live virus fowl pox and pigeon pox vaccines for control of quail pox virus NK992/43 isolate. Kasetsart Veterinarians, 13 (3): 24-31. Available https://www.researchgate.net/publication/257299122_Experimental_assessm ent_of_live_virus_fowl_pox_and_pigeon_pox_vaccines_for_control_of_quai 1_pox_virus_NK99243_isolate

Radi ZA (2004). An Epizootic of combined Clostridium perfringens, Eimeria spp. and Capillaria spp. Enteritis and Histomonas spp. hepatitis with Escherichic coli septicemia in Bobwhite quails (Colinus virginianus). International Journal of Poultry Science, 3 (7): 438-441. DOI: https://doi.org/10.3923/ijps.2004.438.441

Rao JR, Sharma NN, Iyer PKR, and Sharma AK (1990). Interaction between Eimeria uzura infection and aflatoxicosis in Japanese quail (Coturnix coturnix japonica). Veterinary Parasitology, 35 (3): 259-267. DOI https://doi.org/10.1016/0304-4017(90)90060-O

Rasouli-Hiq AA, Bagherzadeh-Kasmani F, Mehri M and Karimi-Torshizi MA (2016). Nigella sativa (black cumin seed) as a biological detoxifier in diet contaminated with aflatoxin B1. Journal of Animal Physiology and Animal Nutrition, 101 (5): e77-e 86. DOI: https://doi.org/10.1111/jpn.12562

Redoy MRA, Shuvo AAS and Al-Mamun M (2017). A review on present status, problems and prospects of quail farming in Bangladesh. Bangladesh Journal of Animal Science, 46(2): 109-120. DOI https://doi.org/10.3329/bjas.v46i2.34439.

Reece RL, Barr DA and Owen AC (1981). The isolation of Haemophilus paragallinarum from Japanese quail. Australian Veterinary Journal, 57: 350351. DOI: https://doi.org/10.1111/j.1751-0813.1981.tb05851.x

Reece RL, Ireland L and Barr DA (1986). Infectious sinusitis associated with Mycoplasma gallisepticum in game-birds. Australian Veterinary Journal, 63: 167-168. DOI: https://doi.org/10.1111/j.1751-0813.1986.tb02963.x

Rigobelo EC, Blackall PJ, Maluta RP and de Ávila FA (2013). Identification and antimicrobial susceptibility patterns of Pasteurella multocida isolated from chickens and Japanese quails in Brazil. Brazilian Journal of Microbiology, 44 (1): 161-164. DOI: http://dx.doi.org/10.1590/S1517-83822013000100023.

Rinaldi A, Mahnel H, Nardelli L, Andelli GC, Cervio G and Valeri A (1972). Charakterisierung eineswachtelpockenvirus. Zenterblant Veterinary Medicine B, 19: 199-212.

Ritter GD, Ley DH, Levy M, Guy J and Barnes HJ (1986). Intestinal cryptosporidiosis and reovirus isolation from Bobwhite quail (Colinus virginianus) with enteritis. Avian Diseases, 30: 603-608. Available at: https://www.ncbi.nlm.nih.gov/pubmed/3021104

Roy P, Purushothaman V, Koteeswaran A and Dhillon AS (2006). Isolation, characterization, and antimicrobial drug resistance pattern of Escherichia coli 
isolated from Japanese quail and their environment. Journal of Applied Poultry Research, 15 (3): 442-446. DOI: https://doi.org/10.1093/japr/15.3.442

Ruskin FR (1991). Quail. In: Microlivestock: Little known small animals with promising economic Future. BOSTID, National Research Council, National Academic Press, Washington, DC. pp. 147-55. Available at: https://www.nap.edu/catalog/1831/microlivestock-little-known-small animals-with-a-promising-economic-future.

DOI: https://doi.org/10.17226/1831

Saad MA, Abd-Elhady AI and El-Nagar A (2010). Study on immune response of quail for avian influenza vaccines. Journal of the American Science, 6 (12): 1475-1478. Available at: http://www.americanscience.org

Sah RL, Mall MP and Mohanty GC (1982). Cutaneous candidiasis in Japanese quail (Coturnix coturnix japonica). Mycopathology, 80: 33-37. DOI: https://doi.org/10.1007/BF00437176

Saito T, Watanabe C, Takemae N, Chaisingh A, Uchida Y, Buranathai C, Suzuki H, Okamatsu M, Imada T, Parchariyanon S et al. (2009). Pathogenicity of highly pathogenic avian influenza viruses of $\mathrm{H} 5 \mathrm{~N} 1$ subtype isolated in Thailand for different poultry species. Veterinary Microbiology, 133: 65-74. Available at: https://www.ncbi.nlm.nih.gov/pubmed/18675524

Sakamoto MI, Murakami AE, Fernandes AM, Ospina-Rojas IC, Nunes KC and Hirata AK. (2018). Performance and serum biochemical profile of Japanese quail supplemented with silymarin and contaminated with aflatoxin B1. Poultry Science, 97 (1): 159-166. DOI: https://doi.org/10.3382/ps/pex277

Sander J, Hudson CR, Dufour-Zavala L, Waltman WD, Lobsinger C, Thayer SG, Otalora R and Maurer JJ (2001). Dynamics of Salmonella contamination in a commercial quail operation. Avian Diseases, 45 (4):1044-1049. Available at: https://www.ncbi.nlm.nih.gov/pubmed/11785876

Sarkadi J, Jankovics M, Kis Z, Skare J, Fodor K, Gonczol E, Visontai I, Vajo Z and Jankovics I (2013). Protection of Chinese painted quails (Coturnix chinensis) against a highly pathogenic $\mathrm{H} 5 \mathrm{~N} 1$ avian influenza virus strain after vaccination. Archives of Virology, 158 (12):2577-2581. DOI: https://doi.org/10.1007/s00705-013-1754-Z

Sawhney DS, Vadehra DV and Baker RC (1973). Aflatoxicosis in the laying Japanese quail (coturnix coturnix japonica). Poultry Science, 52: 465-473. DOI: https://doi.org/10.3382/ps

Schat KA, Gonzalez J, Solonzano A, Avila E and Witter RL (1976). A lymphoproliferative disease in Japanese quail. Avian Diseases, 20: 153-161. Available at: https://www.jstor.org/stable/1589484

Sehu A, Cakir S, Cengiz Ö, Essiz D (2005). Mycotox ${ }^{\circledR}$ and aflatoxicosis in quails. British Poultry Science, 46:520-524. DOI: https://doi.org/10.1080/00071660500181529

Sharawi S, El-Habbaa AS, Heba MZ and Khodeir MH (2015). Experimental infection of quail by NDV and its immune response to vaccination. Benha Veterinary Medical Journal, 29 (2): 218-224. Available at: http://bvmj.bu.edu.eg/issues/29-2/26.pdf

Sharma D, Asrani RK, Ledoux DR, Rottinghaus GE and Gupta VK (2012). Toxic interaction between fumonisin B1 and moniliformin for cardiac lesions in Japanese quail. Avian Diseases, 56: 545-554. DOI: https://doi.org/10.1637/10036-121111-Reg.1

Shehata AA, Sedeik ME, Elbestawy AR, Zain El-Abideen MA, Ibrahim HH, Kilany WH and Ali A (2019). Co-infections, genetic, and antigenic relatedness of avian influenza H5N8 and H5N1 viruses in domestic and wild birds in Egypt. Poultry Science, 98 (6): 2371-2379. Available at: https://www.ncbi.nlm.nih.gov/pubmed/30668795

Shemshadi B, Shahrokh RB and Mohsen M (2014). Study on parasitic infections of quails in Garmsar, Iran. International Journal of Advanced Biology and Biomedical Research, 2 (2): 262-266. Available at: http://www.ijabbr.com/article_7075_935363d4ea2999446b37d1fff2ade1a2.p df

Shivaprasad HL, Uzal F, Kokka R, Fisher DJ, McClane BA and Songer AG (2008). Ulcerative enteritis-like disease associated with Clostridium perfringens type $\mathrm{A}$ in Bobwhite quail (Colinus virginianus). Avian Diseases, 52 (4): 635-640. DOI: https://doi.org/10.1637/8341-050108-Reg.1

Simiyoon L, Arulmozhi A and Balasubramaniam GA (2018). Pathology of caecal coccidiosis in Japanese quails (Coturnix coturnix japonica). International Journal of Science and Environmental Technology, 7 (1): 299-302. Available at: http://www.ijset.net/journal/2047.pdf

Singh A, Bekele AZ, Patnayak DP, Jindal N, Porter RE, Mor SK and Goyal SM (2016). Molecular characterization of quail bronchitis virus isolated from Bobwhite quail in Minnesota. Poultry Science, 95: 2815-2818. DOI: http://dx.doi.org/10.3382/ps/pew217
Singh A, Oberoi MS and Singh B (1995). Pathogenicity in quail's inclusion body hepatitis virus (avian adenovirus-1) for Japanese quails and broiler chicks. Veterinary Research Communication, 545-551. DOI https://doi.org/10.1007/BF01839342

Singh H, Grewal GS and Singh N (1994). Mycotic salpingitis in a Japanese quail (Coturnix coturnix japonica). Avian Diseases, 38 (4): 910-913. Available at: https://www.ncbi.nlm.nih.gov/pubmed/7702530

Singh SD, Mohanty GC and Kataria JM (1992). Vascular and cellular reactions in quail skin induced by fowl poxvirus. Indian Journal of Veterinary Pathology, $16:$
https://dergipark.org.tr/tr/pub/tbtkveterinary/issue/12545/151389

Sokół R, Gesek M, Raś-Noryńska M and Michalczyk M (2014). Toltrazuri $\left(\right.$ Baycox $\left.{ }^{\circledR}\right)$ treatment against coccidiosis caused by Eimeria sp. in Japanese quails (Coturnix coturnix japonica). Polish Journal of Veterinary Sciences, 17 (3): 465-468. Available at: https://europepmc.org/abstract/med/25286655

Susta L, Segovia D, Olivier TL, Dimitrov KM, Shittu I, Marcano V and Miller PJ (2018). Newcastle disease virus infection in quail. Veterinary Pathology, 55 (5): 682-692. DOI: https://doi.org/10.1177\%2F0300985818767996

Tabbu CR (2000). Penyakit Ayam dan Penanggulangannya. Kanisius: Yogyakarta 1: $14-20$

Takahashi S, Inooka S and Mizuma Y (1984): Selective breeding for high and low antibody responses to inactivated Newcastle disease virus in Japanese quails. Poultry Science, 63 (4):595-599. DOI: https://doi.org/10.3382/ps.0630595

Takashima I, Hiyoshi M, Kariwa H, Mukaiya R and Hashimoto N (1996). Experimental Chlamydia psittaci infection of Japanese quail. Microbiology and Immunology, 40 (4): 265-270. DOI: https://doi.org/10.1111/j.1348$0421.1996 . t b 03345 . x$

Takata T, Liang J, Nakano H and Yoshimura Y (2003). Invasion of Salmonella enteritidis in the tissues of reproductive organs in laying Japanese quail: an immunocytochemical study. Poultry Science, 82: 1170-1173. DOI: https://doi.org/10.1093/ps/82.7.1170

Tashiro M, Reinacher M and Rott R (1987). Aggravation of pathogenicity of an avian influenza virus by adaptation to quails. Archive of Virology, 93: 81-95. DOI: https://doi.org/10.1007/BF01313895

Tavakkoli H and Gooshki SN (2014). The effect of doxycycline on the viability of the quail embryo during incubation period. International Journal of Advanced Biological and Biomedical Research, 2 (8): 2390-2394.

Teixeira M and Lopes CWG (2002). Species of the genus Eimeria (Apicomplexa: Eimeriidae) from Japanese quails (Coturnix japonica) in Brazil and Eimeria fluminensis for the preoccupied Eimeria minima of this quail. Revista Brasileira de Ciência Avícola, 9 (1): 53-56. Available at: https://eurekamag.com/research/003/941/003941421.php

Teixeira M, Teixeira FWL and Lope CWG (2004). Coccidiosis in Japanese quails (Coturnix japonica) characterization of a naturally occurring infection in a commercial rearing farm. Revista Brasileria de Ciencia Avicola, 6: 129-134. DOI: http://dx.doi.org/10.1590/S1516-635X2004000200010

Tham VL, Kniesberg S and Dixan BR (1982). Cryptosporidiosis in quail. Avian Diseases, 11: 619-626. DOI: https://doi.org/10.1080/03079458208436138

Theilen GH, Zeiget RF and Twiehaus A (1966). Biological studies with RE virus (strain T) that induces reticuloendotheliosis in turkeys, chickens and Japanese quail. Journal of National Cancer Institute, 37: 731-743. Available at: https://www.tandfonline.com/doi/pdf/10.1080/03079458208436119

Thenmozi V and Malmarungan S (2013). Isolation and identification and antibiogram pattern of Avibacterium paragallinarum from Japanese quails. Tamil Nadu Journal of Veterinary Animal Science, 9: 253-258. Available

at:https://pdfs.semanticscholar.org/f2a4/d11fc7fceb2277550b5a1060c36d559 a69a8.pdf

Tiensin T, Chaitaweesub P, Songserm T, Chaisingh A, Hoonsuwan W, Buranathai C, Parakamawongsa T, Premashthira S, Amonsin A, Gilbert M et al. (2005). Highly pathogenic avian influenza H5N1. Thailand, 2004. Emerging Infectious Diseases, 11: 1664-1672. DOI: https://dx.doi.org/10.3201\%2Feid1111.050608

Tiong SK (1978). Isolation of Mycoplasma gallisepticum from sinuses of three quails (Coturnix coturnix japonica). Veterinary Record, 103: 539. DOI: https://doi.org/10.1136/vr.103.24.539

Tiwari R, Wani MY and Dhama K (2011). Candidiasis (moniliasis, thrush or sour crop) in poultry: An overview. Poultry Technology, 6: 110-111.

Tripathy DN and Reed WM (1997). Pox. In: Calnek, B.W., Barnes, H.J., Beard, C.W., McDougald, L.R., Saif, Y.M., Eds.: Diseases of Poultry. 10th ed., Iowa State University Press, Ames, Iowa, pp. 643-659. 
Tsai SS, Chang TC, Chang GN, Chern RS, Chien MS and Itakura C (1998). Naturally-occurring adenovirus-associated gastrointestinal lesions in Coturnix (Coturnix coturnix) quail. Avian Pathology, 27(6): 641-643. Available at: https://www.ncbi.nlm.nih.gov/pubmed/18484054

Türkyilmaz S, Cöven F and Esk S (2007). Detection of antibodies produced in quails (Coturnix coturnix japonica) against Mycoplasma gallisepticum with different serological tests. Turkish Journal of Veterinary Animal Science, 31 (4): 267-270. Available at: http://citeseerx.ist.psu.edu/viewdoc/download?doi=10.1.1.867.9111\&rep=rep $1 \&$ type $=$ pdf.

Uddin MB, Ahmed SSU, Hassan MM, Khan SA and Mamun MA (2010). Prevalence of poultry diseases at Narsingdi, Bangladesh. International Journal of Bioresearch, 1: 09-13. Available at: https://www.researchgate.net/profile/Md_Bashir_Uddin/publication/2220905 38_Prevalence_of_poultry_diseases_at_Narsingdi_Ban_gladesh/links/004635 32 fde 6

Udhayavel S, Murthy TRGK, Gowthaman V, Senthilvel K and Kumar GS (2016). Isolation and identification of Salmonella enterica from Japanese quail in India. International Journal of Applied Research, 2 (12): 645-647. Available at: http://www.allresearchjournal.com/archives/2016/vol2issue12/PartJ/2-1296-762.pdf

Umar HA, Lawal IA, Okubanjo OO and Wakawa AM (2014). Morphometric identification, gross and histopathological lesions of Eimeria species in Japanese quails (Coturnix coturnix japonica) in Zaria, Nigeria. Journal of $\begin{array}{llll}\text { Veterinary } & \text { Medicine, } & \text { 2014: }\end{array}$ http://dx.doi.org/10.1155/2014/451945

Usman BA, Mani AU, El-Yuguda AD and Diarra SS (2008). The Effect of supplemental ascorbic acid on the development of Newcastle disease in Japanese quail (Coturnix coturnix Japonica) exposed to high ambient temperature. International Journal of Poultry Science, 7 (4): 328-332. Available at: http://agris.fao.org/agrissearch/search.do?recordID=US201301687433

Wahyuni AETH, Tabbu CR, Artanto S, Setiawan DCB and Rajaguguk SI (2018). Isolation, identification, and serotyping of Avibacterium paragallinarum from quails in Indonesia with typical infectious coryza disease symptoms. Veterinary World, 11(4): 519-524. Available at: http://www.veterinaryworld.org/Vol.11/April-2018/17.html

Wan H and Perez DR (2006). Quail carry sialic acid receptors compatible with binding of avian and human influenza viruses. Virology, 346: 278-286. Available at: https://www.ncbi.nlm.nih.gov/pmc/articles/PMC5003610/

Wang G, Zhan D, Li L, Lei F, Liu B, Liu D, Xiao H, Feng Y, Li J, Yang B et al. (2008). H5N1 avian influenza re-emergence of Lake Qinghai: phylogenetic and antigenic analyses of the newly isolated viruses and roles of migratory birds in virus circulation. Journal of Genetic Virology, 89: 697-702. DOI: https://dx.doi.org/10.1099\%2Fvir.0.83419-0

Webster RG, Guan Y, Peiris M, Walker D, Krauss S, Zhou NN, Govorkova EA Ellis TM, Dyrting KC, Sit T et al. (2002). Characterization of H5N1 influenza viruses that continue to circulate in geese in Southeastern China. Journal of Virology, 76:118-126. Available at: https://www.ncbi.nlm.nih.gov/pubmed/11739677

Wee SH, Park CK, Nam HM, Kim CH, Yoon H, Kim SJ, Lee ES, Lee BY, Kim JH, Lee JH et al. (2006). Outbreaks of highly pathogenic avian influenza (H5N1) in the Republic of Korea in 2003/04. Veterinary Record, 158: 341-344. DOI https://doi.org/10.1136/vr.158.10.341

Wight PAL (1963). Lymphoid leucosis and fowl paralysis in the quail. Veterinary Record, 75: 685-687. Available

Winterfield RW and Reed W (1985). Avian pox: Infection and immunity with quail, psittacine, fowl, and pigeon pox viruses. Poultry Science, 64: 65-70. Available

http://citeseerx.ist.psu.edu/viewdoc/download?doi=10.1.1.1008.4855\&rep=re p1\&type $=$ pdf

Yambayamba KES and Chileshe PC (2019). Effect of increased photoperiod on feed intake, egg production and Egg size in Japanese quail (Coturnix japonica) under Zambian conditions. EC Veterinary Science. 45: 334-342. Available at: https://www.ecronicon.com/veterinary-science.php

Yakubu D, Moshood R, Paul A, Sunday O, Lola OM and Ayodeji Oluwadare O (2015). Clinicopathological features in Japanese quails (Coturnix coturnix japonica) inoculated with Pasteurella multocida serotypes A: 1, 3 and 4. World's Veterinary Journal, 5 (2): 26-30. DOI http://dx.doi.org/10.5455/wvj.20150451

Yavuz O, Özdemir Ö, Ortatatli M, Atalay B, Hatipoglu F and Terzi F (2017). The preventive effects of different doses of glucomannan on experimental aflatoxicosis in Japanese quails. Brazilian Journal of Poultry Science, 19 (3) 409-416. DOI: http://dx.doi.org/10.1590/1806-9061-2016-0349

Yee KS, Novick CA, Halvorson DA, Dao N, Carpenter TE and Cardona CJ (2011). Prevalence of low pathogenicity avian influenza virus during 2005 in two U.S. live bird market systems. Avian Diseases, 55: 236-242. DOI: https://doi.org/10.1637/9427-061610-Reg.1

Zhang Z, Hu W, Li B, Chen R, Shen W, Guo H, Guo H and Li H (2019). Comparison of viremia, cloacal virus shedding, antibody responses and pathological lesions in adult chickens, quails, and pigeons infected with ALV-A. $\quad$ Scientific Reports, 9 (3027): 1-9. DOI: https://doi.org/10.1038/s41598-019-39980-y 